\title{
Hydrological and biogeochemical dynamics of the minor and trace elements in the St. Lawrence River
}

\author{
Bernard Rondeau $^{a}$, Daniel Cossa $^{b^{*}}$, Pierre Gagnon $^{a}$, Thanh T. Pham $^{a}$ and Charline Surette ${ }^{a}$ \\ ${ }^{\mathrm{a}}$ St. Lawrence Centre, Environment Canada, 105 McGill, Montréal, Que., Canada H2Y 2E7 \\ bInstitut Français de Recherche pour l'Exploitation durable de la Mer, BP 21105, F.44311 Nantes Cedex 3 ,
} France

*: Corresponding author : Tel.: +33 2403741 76; fax: +33 2403740 75. dcossa@ifremer.fr

\begin{abstract}
:
Surface water samples from the St. Lawrence River were collected in order to study the processes controlling minor and trace elements concentrations ( $\mathrm{Al}, \mathrm{Fe}, \mathrm{Mn}, \mathrm{Cd}, \mathrm{Co}, \mathrm{Cu}, \mathrm{Ni}$ and $\mathrm{Zn}$ ), and to construct mass balances allowing estimates of the relative importance of their natural and anthropogenic sources. The two major water inputs, the upper St. Lawrence River, which drains waters originating from the Lake Ontario, and the Ottawa River were collected fortnightly over 18 months. In addition, other tributaries were sampled during the spring floods. The output was monitored near Quebec City at the river mouth weekly between 1995 and 1999. Dissolved metal concentrations in the upper St. Lawrence River carbonated waters were lower than in the acidic waters of the tributaries draining the crystalline rocks of the Canadian shield and the forest cover. Biogeochemical and hydrodynamic processes occurring in Lake Ontario drive the seasonal variations observed in the upper St. Lawrence River. Biogeochemical processes relate to biological uptake, regeneration of organic matter (for $\mathrm{Cd}$ and $\mathrm{Zn}$ ) and oxyhydroxide formation (for $\mathrm{Mn}$ and $\mathrm{Fe}$ ), while hydrodynamic processes mainly concern the seasonal change in vertical stratification (for $\mathrm{Cd}, \mathrm{Mn}$, and $\mathrm{Zn}$ ). In the Ottawa River, the main tributary, oxyhydroxide formation in summer governs seasonal patterns of $\mathrm{Al}$, $\mathrm{Fe}, \mathrm{Mn}, \mathrm{Cd}, \mathrm{Co}$ and $\mathrm{Zn}$. The downstream section of the St. Lawrence River is a transit zone in which seasonal variations are mainly driven by the mixing of the different water masses and the large input of suspended particulate matter from erosion. The budget of all dissolved elements, except Fe and Zn, was balanced, as the budget of particulate elements (except $\mathrm{Cd}$ and $\mathrm{Zn}$ ). The main sources of metals to the St. Lawrence River are erosion and inputs from tributaries and Lake Ontario. Direct anthropogenic discharges into the river accounted for less than $5 \%$ of the load, except for $\mathrm{Cd}(10 \%)$ and $\mathrm{Zn} \mathrm{(21 \% ).} \mathrm{The} \mathrm{fluxes} \mathrm{in} \mathrm{transfer} \mathrm{of} \mathrm{dissolved} \mathrm{Cd}, \mathrm{Co}, \mathrm{Cu}$ and $\mathrm{Zn}$ species from the river to the lower St. Lawrence estuary were equal to corresponding fluxes calculated for Quebec City since the distributions of dissolved concentrations of these metals versus salinity were conservative. For Fe, the curvature of the dilution line obtained suggests that dissolved species were removed during early mixing.
\end{abstract}

Keywords: Trace element, biogeochemistry, river, mass balance, St. Lawrence 


\section{INTRODUCTION}

The St. Lawrence River (SLR), one of the largest rivers in the world, drains sub Basins with contrasting lithologies and weather conditions, which are subject to various land uses and other anthropogenic disturbances. This immense region is underlain by carbonated and crystalline rocks and quaternary sea sediments and covered by forest, farms and urban areas (Fig. 1). Consequently, the chemical composition of the SLR varies from its source (Lake Ontario) to its mouth (Quebec City) (Janson and Sloterdjick 1982; Tremblay and Cossa, 1987; Yang et al., 1996). The highly carbonated waters characteristic of Lake Ontario are altered downstream by inputs of tributaries, especially the poorly mineralized Ottawa and St. Maurice Rivers, the two main tributaries draining the Precambrian Shield on the north shore, an area largely covered with forests that provide good protection against erosion. On the contrary, the southern tributaries 
drain urbanized, industrialized and agricultural areas of Paleozoic limestones and the Canadian Appalachians (e.g., Yang et al., 1996). The main lacustrine feature at the source of the St. Lawrence (Lake Ontario) is the very low load of suspended particulate matter (SPM). However, inputs of particles from the tributaries of the southern sub-basins and by the adjunct of material from erosion of its banks and bed load change this aspect (Rondeau et al., 2000). Another effect of the lacustrine regime is seasonal hydrologic stability, which is reinforced by regulation of the flow at the Cornwall dam above Montreal, whereas the tributaries display marked hydrologic regimes. Thus, the diversity of its features makes the SLR a good experimental model for studying the biogeochemical and hydrological processes that control element concentrations in natural waters.

Major ion composition has been largely described for the SLR (e.g., Tremblay and Cossa, 1987; Rondeau, 1993), and the dynamics of carbon, strontium and sulfur studied (Pocklington, 1982; Yang et al, 1996). However, little is known about the composition and the behavior of minor and trace elements. Cossa et al. (1990) noted the seasonality of iron and manganese distribution at the river mouth. Only cadmium and mercury chemistry have recently been explored significantly (Lum, 1987; Quémerais et al., 1998; Quémerais et al., 1999; Lalonde et al., 2001). Time series are important for understanding reactivity, identifying sources and calculating transport (Shiller, 1997). In the present study, a time series was obtained for 8 minor and trace metals (dissolved and particulate) at three main stations along the St. Lawrence. Our objectives were to investigate the biogeochemical and hydrological processes that control element concentrations and provides a mass balance budget for the metals studied by identifying sources and estimating the loading to receiving waters. 


\section{ENVIRONMENTAL SETTINGS}

The St. Lawrence River ranks 15 th in the world for mean annual water discharge. It drains a total area of more than 1.3 million $\mathrm{km}^{2}$, including the Great Lakes basin, and has a total length of nearly $1200 \mathrm{~km}$ between its source at the outlet of Lake Ontario and its mouth into the Gulf of St. Lawrence (Fig. 1). The main urban and industrialized areas are located around the Great Lakes and in the Montreal area. The total population of the basin is around 40 million inhabitants, with 5 million in the SLR valley itself, mainly concentrated in Montreal and its suburbs. The fluvial section of the St. Lawrence extends from Cornwall to Quebec City (Fig. 1). In this section, the SLR is composed of two main water masses, the Ontario Lake and the Ottawa River (its main tributary), and also receives inputs from numerous smaller tributaries (Fig. 1, Table 1). Tributaries on the north shore make up $10 \%$ of the discharge at the river mouth during low water periods, but contribute 55\% during periods of high water. The variations in the flow of St. Lawrence tributaries subsequent to winter snow accumulation and spring thaw is the dominant hydrological event for the river (Table 1). These variations double river discharge in the Quebec City area during spring snowmelt. Water flow from the Great Lakes is quite stable throughout the hydrological year (Table 1). Discharge measured at the Cornwall station does not reflect the natural hydrological cycle, but rather the controlled flow of regulated water levels by the three dams (Iroquois, Moses Saunders and Long Sault) between the outlet of Lake Ontario and Cornwall.

The SLR drains a basin comprising the crystalline rocks of the Canadian Shield on the north shore and clays deposited as Champlain Sea sediments during the last marine invasion on the south shore. While the north shore tributary basins are occupied by forest, the banks of Lake 
Ontario and the SLR are largely used for agriculture. The chemical characteristics of the waters are highly controlled by the geology of the catchment basins (e.g., Yang et al., 1996). Hierarchical cluster analyses, based on major ions concentrations (Bobée et al., 1980; Yang et al., 1996) underlie the typology shown in Table 1. The three different types of water correspond to the geology of the various catchments. The water of the tributaries draining the Canadian shield (north-shore tributaries) have very low dissolved major ions and high dissolved organic carbon concentrations (Table 1). Waters from Lake Ontario and the tributaries from the south shore are more mineralized, but differ with respect to their particulate matter content (Table 1). The upper SLR waters at Cornwall show the typical composition of the Lake Ontario outflow for numerous chemical compounds (Cossa et al., 1998; Yang et al., 1996). At that point, the waters are crystal clear, since the lake constitutes a sedimentary basin, whereas the south shore tributaries carry high sediment loads. In addition, the bed and banks of the SLR itself are currently eroding and are thought to constitute the largest source of the SPM transported downstream (Rondeau et al., 2000).

Temporal variations of major elements of the two main water masses, the Ontario Lake and the Ottawa River, are low. Seasonal variations at the mouth of the river are clearly related to changes in the relative contribution of these two main sources during hydrological cycle. For example, the curve for $\mathrm{Ca}$ illustrates the variation of concentrations at the mouth of the river, corresponding to the dilution between these two end-sources (Fig. 2).

\section{SAMPLING METHODS, FILTRATION AND ANALYSES}

Sampling was conducted weekly or monthly, depending on the water regime of the St. Lawrence and on the expected variability in contaminant concentrations, and additional samples 
were obtained during periods of flooding. Surface water samples were collected at three main stations along the river (Fig. 1): the upper SLR at Cornwall (composed almost exclusively of Lake Ontario waters), the mouth of the Ottawa River (the major St. Lawrence tributary) at Carillon, and Quebec City, the furthest downstream point before the waters becomes brackish. At Cornwall and Carillon, sampling sites were located in the main channel, and samples were collected at $1 \mathrm{~m}$ below the water surface. At Quebec City, samples were collected from the municipal drinking water intake at a depth of approximately $10 \mathrm{~m}$. A previous study showed that the water column at Quebec City is well mixed vertically and the water collected at the municipal intake is representative of the St. Lawrence water mass (Rondeau, 1998). In addition, the Richelieu, St. François, Yamaska and Nicolet Rivers were sampled during spring 1996 at their confluence with the SLR. Analysis was also carried out on samples collected during spring 1995 in the St. Maurice River at its confluence with the SLR.

Samples were collected using a pneumatic Teflon pump and tubing. In the field, the pump and tubing were thoroughly rinsed with surface water at each sampling site prior to sample collection. All material in contact with samples was acid-washed and rinsed beforehand. Samples were filtered under a HEPA-filtered laminar flow bench (class 100) using $0.4 \mu \mathrm{m}$ pore size polycarbonate membranes $47 \mathrm{~mm}$ diameter. Filtration was performed within $4 \mathrm{~h}$ of collection according to the procedure described in detail elsewhere (Cossa et al., 1996; Rondeau et al. 2000). After the first $50 \mathrm{~mL}$ were discarded, the filtrates were collected in LDPE bottles, acidified $\left(\mathrm{HNO}_{3} 0.1 \% \mathrm{v} / \mathrm{v}\right.$, Seastar), and kept in two polyethylene bags until analysis. Dissolved $\mathrm{Co}, \mathrm{Cu}, \mathrm{Zn}, \mathrm{Al}, \mathrm{Mn}$ and $\mathrm{Ni}$ were determined by inductively coupled plasma-mass spectrometry (ICP-MS) in the Chemistry Department of the Montreal University (1995-1997) and the Maurice Lamontagne Institute, Department of Fisheries and Oceans (1998-1999). Dissolved Fe was 
determined by inductively coupled plasma-atomic emission spectrometry (ICP-AES) and Cd by graphite furnace atomic absorption spectrophotometry (GFAAS) after preconcentration (by a factor of 10) by evaporation under a HEPA-filtered laminar flow bench (class 100). Suspended particulate matter samples collected on filtration membranes $(0.4 \mu \mathrm{m})$ were digested using $\mathrm{HNO}_{3} / \mathrm{HF}\left(2: 1 \mathrm{v} / \mathrm{v}\right.$, Seastar) in Teflon reactors $\left(125^{\circ} \mathrm{C}, 1 \mathrm{~h}\right)$ and analyzed by GFAAS (Cd, Co, $\mathrm{Cu}, \mathrm{Ni}$ ) or ICP-AES (Al, Fe, Mn, Zn). The sampling and analytical methods have been fully detailed elsewhere (Cossa et al., 1996; Dumouchel et al., 1998). Accuracy for dissolved metals was checked regularly using SLRS-3 (Riverine Water Reference Material for Trace Metals certified by the National Research Council of Canada). For particulate metals, accuracy was determined by analysis of MESS-1 (National Research Council of Canada). The means of the values measured for these certified reference materials were in agreement with the certified concentrations (Table 2). The blank signal was determined using acidified Milli-Q-UV-Plus water (for dissolved metals), which was stored in an identical manner as for samples; unused blank filters were also digested (for particulate metals). As blank for dissolved metals were below detection limits and the methodological detection limits (US EPA, 1984) were used. For particulate metals, detection limits was determined using 3 standard deviations of the blank. Table 2 lists the mean blank trace element concentrations and detection limits.

\section{RESULTS AND DISCUSSION}

\subsection{End-member sources}

The end-member sources considered here for the SLR are (1) upper SLR waters at Cornwall, which have the typical composition of Lake Ontario outflow for numerous chemical compounds 
(Cossa et al., 1998), (2) the Ottawa River at Carillon, considered as representative of the northshore tributaries (Cossa et al., 1998), (3) several south-shore tributaries, namely Richelieu, St. François, Yamaka, and Nicolet Rivers, and (4) an internal particulate matter source constituted by erosion of the SLR bed and banks (Rondeau et al., 2000). The rivers were sampled during the water year 1995-96: 39 and 42 times throughout the year for the first two stations respectively, between 8 and 15 times for the south-shore tributaries, especially during the spring runoff in 1996. The main chemical characteristics of these waters are gathered in table 1 . The eroded material consisted of Champlain Sea sediments with an elemental composition close to that of the earth crust (Table 2).

\subsubsection{Hydrograms and sedimentograms}

The Cornwall hydrogram was stable during the sampling period, showing no obvious seasonal variation owing to flow controls exerted by the dams (Fig. 3B). On the Ottawa River near its confluence with the upper SLR, the hydrogram showed more seasonal variation, despite flow control. South-shore tributaries displayed distinct pulses in spring, corresponding to lag between the snowmelts period of the various catchments.

The concentrations of SPM at Cornwall showed only small seasonal variations (mean $=1.0$ $\mathrm{mg} \mathrm{L} \mathrm{L}^{-1}$, standard deviation $=0.6 \mathrm{mg} \mathrm{L}^{-1}, \mathrm{n}=39$ ). Two types of particles were found in Lake Ontario outflow: organic-rich particles (40 to $70 \%$ by weight) collected in spring 1995 and summer 1996, and less rich particles (8-25\% organic) during other seasons. A statistically significant relationship was observed between POC and chlorophyll $a(\mathrm{r}=0.58, \mathrm{n}=39)$, indicating the increase importance of the algae fraction during warm seasons. These results are quite consistent with the expectation, as the waters originate from the Lake Ontario, which acts as a sedimentary basin with a biologically productive epilimnion during summer. 
The Ottawa River showed a mean SPM of $7.3 \mathrm{mg} \mathrm{L}^{-1}$ and much larger seasonal variations ( standard deviation $=9.9 \mathrm{mg} \mathrm{L}^{-1}, \mathrm{n}=42$ ). During the 1996 spring runoff, SPM reached $60 \mathrm{mg} \mathrm{L}^{-1}$ for a water discharge of $5000 \mathrm{~m}^{3} \mathrm{~s}^{-1}$ (Fig. 3A). Average organic carbon content was $8.4 \%$, whereas SPM and water discharge (unlike the results for outflow from Lake Ontario) were covariant with lower organic carbon content (down to $2.4 \%$ ) during the 1996 spring runoff.

The south-shore tributaries had the highest mean SPM (around $25 \mathrm{mg} \mathrm{L}^{-1}$ ), but the lowest carbon contents (Table 1).

\subsubsection{Minor elements (Al, Fe and Mn)}

Table 2 reports the summary statistics for dissolved and particulate minor and trace element concentrations. The most striking feature was the very low concentrations of dissolved $\mathrm{Al}, \mathrm{Fe}$ and $\mathrm{Mn}$ in the waters from Lake Ontario (Cornwall) as compared to the corresponding concentrations in tributaries. The highest mean concentrations of dissolved $\mathrm{Al}$ and $\mathrm{Mn}$ were found in southshore tributaries (up to 1141 and $373 \mathrm{nmol} \mathrm{L}^{-1}$ respectively), except the Richelieu River. The discrepancies between concentrations in the upper SLR and its tributaries also concerned particulate $\mathrm{Fe}$ and $\mathrm{Al}$, and to a lesser extent for particulate $\mathrm{Mn}$. The minor element composition of SPM from tributaries was quite similar to concentrations in the earth's crust (Table 2), whereas that of the upper SLR was poor. This is consistent with the high level of organic carbon content in particles collected at Cornwall (Table 1).

Temporal variations of the minor elements exhibited significant seasonal patterns (Fig. 4). The concentrations of dissolved $\mathrm{Mn}$ in the Ottawa River pattern is a particularly striking example, showing maximum values in winter and minimum values in summer and during the snow-melt period in spring (Fig. 4). Dissolved Al and Fe displayed comparable variations, but with low concentrations during the snow-melt period, which was quite significant in 1996. In addition, 
particulate Mn distribution mirrored the dissolved seasonal pattern exactly suggesting a Mn phase change. This was not observed for flow periods, especially in the fall 1995 when eroded particles having low Mn concentration are released into the river. When these particles are excluded from the calculation, the correlation coefficient between particulate and dissolved Mn becomes - 0.63 $(n=44)$, suggesting that the dissolved to particulate Mn transfer does not concern eroded material. In summer, particles were four times Mn enriched $\left(\sim 80 \mu \mathrm{mol} \mathrm{g}^{-1}\right)$ than the earth's crust (mean $\sim 14 \mu \mathrm{mol} \mathrm{g}^{-1}$ ) in winter and during floods periods. This suggests that the Mn carrier phase is seasonally dependent, as already described in other surface natural waters (e.g., Stumm and Morgan, 1996). Ponter et al. (1992), in studies concerning the Kalix River (Sweden), reported very similar Mn behavior in comparable geographical conditions, i.e. Precambrian lithology, boreal forest cover, sub-boreal climate and head lakes. They correlated seasonal variation of $\mathrm{Mn}$ concentrations in lakes with variations in streams and rivers. A temperature-correlated seasonal variation in SPM was found for $\mathrm{Mn} / \mathrm{Al}$ ratio, with a 25 -fold increase in late July as compared to flood periods, which suggest biologically mediated precipitation of a Mn oxyhydroxide phase during summer. In autumn, sedimentation and mineralization of the non-detrital Mn phase in river and upstream lakes produced a steady increase of the dissolved Mn concentration in the river water. Large concentrations of dissolved Mn were built up in the hypolimnion of head lakes during the ice-covered period. Finally, a marked increase of dissolved Mn occurred during snowmelting, which was interpreted as the result of Mn-rich mire water mixing with melting snow. Similar observations and interpretation were subsequently made for other rivers (Congo River : Seyler et Elbaz-Poulichet, 1996 ; Mississippi River : Shiller, 1997). For the Ottawa River, Mn/Al ( $\mathrm{mol} / \mathrm{mol})$, ranging from less than 5 in spring to more than 30 in summer, and the positive relationship $(\mathrm{R}=0.80, \mathrm{n}=33)$ between the distribution coefficient $(\mathrm{Kd})$ for particulate and dissolved phases $\left(\mathrm{Kd}=[\text { Particulate } \mathrm{Mn}]_{\mathrm{mol} / \mathrm{g}} /[\text { Dissolved } \mathrm{Mn}]_{\mathrm{mol} / \mathrm{mL}}\right)$ and temperature are 
consistent with this line of interpretation. A similar relationship was found for $F e(R=0.60, n=$ 33). In fact, the existence of upper basin lakes (Lake Dozois, Grand Lake Victoria, Lake Simard, Lake Temiscaming, etc.) reinforces the geochemical similarity of Ottawa River to the Kalix River. Dissolved $\mathrm{Al}$ and Fe showed a trend similar to that of Mn, which can also logically attributed to oxyhydroxides precipitation. However, the corresponding metal enrichment of particles was not observed, as their oxide concentration changes were probably concealed by the more abundant $\mathrm{Al}$ and $\mathrm{Fe}$ present within the clay crystals analyzed by our $\mathrm{HCl} / \mathrm{HNO}_{3} / \mathrm{HF}$ dissolution technique. In addition, $\mathrm{Al}$ concentrations and, to a lesser extent, those of $\mathrm{Fe}$ were depleted in the dissolved phase during the snow-melting flood period (Fig. 4).

In contrast, dissolved and particulate Mn in the upper SLR displayed an "in phase" seasonal pattern, with minimum values in winter and maximum in summer (Fig. 4). Nonetheless, this discrepancy with the Ottawa River pattern is not so obvious outside the winter and spring seasons when mixing of the epilimnion with deep Lake Ontario waters occurs after the destruction of the summer thermocline. Dissolved Mn and particulate Mn showed inverse patterns, particularly in the summer 1996 (Fig. 4) when particles were much more enriched [Mn/Al $(\mathrm{mol} / \mathrm{mol})=15]$ than in winter $[\mathrm{Mn} / \mathrm{Al}(\mathrm{mol} / \mathrm{mol})=7]$. This suggests that $\mathrm{Mn}$ oxyhydroxides form in the surface waters of Lake Ontario in summer. The low dissolved Mn concentration in winter is consistent with the typical distribution of dissolved Mn in deep oxic lakes, showing lower concentrations in the hypolimnion than in the epilimnion. Indeed, it has been determined that the vertical distribution of dissolved $\mathrm{Mn}$ in Lake Ontario, despite the ten times lag in concentration levels, shows higher concentrations in epilimnion than deep waters (Nriagu et al., 1996). The dissolved Al concentrations were too low $\left(<74 \mathrm{nmol} \mathrm{L}^{-1}\right)$ to be detected by standard analytical protocol. The distribution of dissolved Fe concentrations was quite complex, showing a general tendency 
to low values in summer (consistent with a biological uptake) and several peaks, especially in spring and fall (consistent with increase in runoff). The particulate phase of $\mathrm{Al}$ and $\mathrm{Fe}$, like that of Mn, showed lower concentrations during winter when deep water mixes with the epilimnion.

In summary, the concentrations of $\mathrm{Mn}, \mathrm{Al}$ and $\mathrm{Fe}$ in the main river water sources are governed by the formation of oxyhydroxides and the hydrodynamic forcing of the head lakes.

\subsubsection{Trace elements ( $\mathrm{Cd}, \mathrm{Co}, \mathrm{Cu}, \mathrm{Ni}$ and $\mathrm{Zn})$}

Mean dissolved Cd concentrations in the upper SLR and the Ottawa River $(0.07 \pm 0.04$ and $0.09 \pm 0.05 \mathrm{nmol} \mathrm{L}^{-1}$, Table 2) were very similar and comparable to those measured in the southshore tributaries $\left(0.09-0.10 \mathrm{nmol} \mathrm{L}^{-1}\right)$ five years before (Quémerais and Lum, 1997). Conversely, the particles from Ottawa River and especially the Lake Ontario were Cd-enriched compared to those from the south-shore tributaries. Mean dissolved low $\mathrm{Cu}$ and $\mathrm{Zn}$ concentrations were found in the waters from Lake Ontario (10.4 and $4.6 \mathrm{nmol} \mathrm{L}^{-1}$, respectively), while $\mathrm{Co}, \mathrm{Cu}, \mathrm{Ni}$ and $\mathrm{Zn}$ were high in St. François and Yamaska rivers (3.12, 27.8, 35.3 and 19.6 nmol L ${ }^{-1}$ respectively) which are industrialized and agriculturally active regions. Particulate Co, $\mathrm{Cu}, \mathrm{Ni}$ and $\mathrm{Zn}$ are less variable than $\mathrm{Cd}$ from one water mass to another; however, SPM from Lake Ontario tended to be Zn-enriched and Co- and Ni-depleted (Table 2). The Ottawa River is representative of the north-shore tributaries that drain areas of crystalline rock and forest cover in most catchment basins and show high dissolved metal concentrations (with the exception of $\mathrm{Ni}$ ) promoted by their complexation with organic matter. Modeling the metal speciation using the complexation constants from Mantoura et al. (1978), allows to calculate (from the COD and total dissolved metal concentrations) that the organic metal complexes represent a large fraction of the total dissolved for $\mathrm{Co}, \mathrm{Mn}, \mathrm{Ni}, \mathrm{Zn}$, and $\mathrm{Cu}$ in Ottawa River. 
In Ottawa River, seasonal variations were noted for several metals (Fig. 5). The lower dissolved $\mathrm{Cd}$, Co and $\mathrm{Zn}$ values observed in summer increased steadily in the fall and remained high in winter before decreasing in spring. These seasonal distribution patterns were parallel to that of Mn, except for high runoff periods. If these periods are excluded, the relationships between dissolved $\mathrm{Cd}, \mathrm{Zn}$ and $\mathrm{Co}$ on the one hand and dissolved $\mathrm{Mn}$ on the other are highly significant, with correlation coefficients of $0.69,0.68$ and 0.57 respectively. The Kd (defined as previously for $\mathrm{Mn}$ ) of $\mathrm{Co}$ and $\mathrm{Zn}$ (correlation coefficients of 0.66 and 0.55 ) where also related to the water temperature.

Concentrations of dissolved metals in the upper St. Lawrence River, with the exception of Cd and $\mathrm{Zn}$, which co-varied $(\mathrm{R}=0.62)$ and tended to show high values in winter, were quite stable throughout the 18-month sampling period (Fig. 5). The aquatic cycle of $\mathrm{Cd}$ and $\mathrm{Zn}$ are known to be biologically dependent. They are taken up by phytoplankton during the productive months in the epilimnion, then export by the biogenic particles in the hypolimnion, and finally regenerated in deep waters during the mineralization of particulate organic matter. Thus, these two metals generally show higher concentrations in the deep waters than in surface waters, as observed for $\mathrm{Cd}$ and $\mathrm{Zn}$ in Lake Ontario (Nriagu et al., 1996). Thus, the type of vertical distribution in Lake Ontario waters and winter mixing most likely account for the seasonal variations of dissolved Cd and $\mathrm{Zn}$ observed downstream in the SLR. Moreover, reported concentration levels in the epi- and hypolimnion (Nriagu et al., 1996) are consistent with our summer and winter values at Cornwall.

For the Ottawa River and south-shore tributaries, particulate concentrations increased (Al, Co) or decreased ( $\mathrm{Cd}, \mathrm{Ni}, \mathrm{Zn}, \mathrm{Mn})$ with an augmentation of SPM, reaching a constant concentration levels. The copper concentrations in particles exhibited more complex distributions in these rivers; however, they also tended to match a constant value for the highest SPM levels. The same 
was observed for $\mathrm{Cd}, \mathrm{Cu}, \mathrm{Ni}$ and $\mathrm{Zn}$ in the upper SLR. Rondeau et al. (2000) showed that the high SPM concentrations occurred when high water flow promotes the resuspension of deposited sediments and/or surface runoff involves soil erosion. The resuspended or eroded material shows high $\mathrm{Al}$ and $\mathrm{Co}$, and relatively low $\mathrm{Cd}, \mathrm{Cu}, \mathrm{Ni}$ and $\mathrm{Zn}$ contents compared to the SPM present in the river during the low water discharge periods.

It is noteworthy that particulate $\mathrm{Cd}, \mathrm{Cu}$ and $\mathrm{Zn}$ in the south-shore tributaries were covariant with particulate $\mathrm{Mn}$, showing correlation coefficients of $0.58,0.60$ and 0.62 respectively, suggesting a control of these three trace elements by Mn.

\subsection{River mouth}

The data series presented here concern 190 water samples collected at Quebec City between April 1995 to March 1999.

\subsubsection{Hydrogram and sedimentogram}

Hydrogram at Quebec City indicated that large variations occur in tributary catchment basins during spring snow-melt (Fig. 3E). Water from Lake Ontario accounted for only 19\% of discharge at the river mouth during spring flood periods, but $82 \%$ during low-water periods (Fig. 3D). Spring high discharge Quebec City continues for two months because of the lag times between flood peaks in north- and south-shore tributaries.

SPM concentrations at Quebec City were directly dependent on variations in water discharge (Fig. 3E). They were much higher than those at the end-member sources because of the huge amount of material eroded from the bed and banks of the river, averaging $60 \%$ of the suspended load at the mouth of the River (Rondeau et al., 2000). The lowest concentrations were observed in winter (3 à $\left.4 \mathrm{mg} \mathrm{L}^{-1}\right)$ when the proportion of water from Lake Ontario was maximum (> 80\%). 
Consistently with the POC average concentrations in the main water masses (Table 1), the POC content at Quebec City was inversely correlated with the SPM, constituting 1\% of SPM during spring runoff and $20 \%$ during periods when the proportion of water from Lake Ontario was maximal.

\subsubsection{Minor elements (Al, Fe and Mn)}

Table 2 provides summary statistics for dissolved and particulate minor and trace element concentrations at Quebec City. As expected, the values were within the concentration ranges at the main sources. Dissolved Al, Fe and Mn exhibited clear seasonal patterns, showing maximum values during the spring runoff and a gradual decrease during summer, with a minimum in September (Fig. 6). Fe and Mn showed steady increases in concentrations during fall and winter. Conversely, concentrations of dissolved $\mathrm{Al}$ were stable in fall and winter. With exception of high levels of dissolved $\mathrm{Mn}$ in April, the seasonal patterns of particulate and dissolved Mn were opposite with a correlation coefficient of $-0.58(n=115)$; this observation is consistent with the oxyhydroxide formation in the Ottawa River. In summer, particulate Mn was enriched two-fold $\left(\sim 35 \mu \mathrm{mol} \mathrm{g}^{-1}\right)$ compared to winter values (mean $\sim 20 \mu \mathrm{mol} \mathrm{g}^{-1}$ ) close to earth's crust. During winter, the decreased concentration between the confluence with the Ottawa River and the mouth

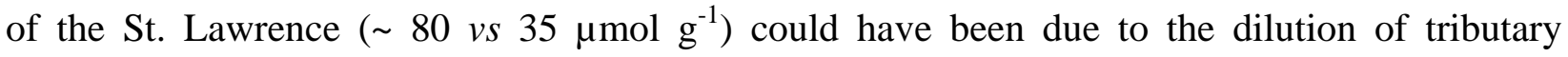
particules by eroded marine clays. Particulate Fe concentrations were quite stable throughout the sampling period (Fig. 6), and particulate $\mathrm{Al}$ showed slightly lower values in winter. No seasonal metal enrichment of particles was observed, because the varying phase (oxides phase) was probably diluted by the $\mathrm{Al}$ and $\mathrm{Fe}$ present within the clay crystals.

The seasonal variation in relative proportions of water masses from end-member during hydrological cycle accounted for the concentrations and seasonal patterns for dissolved minor 
elements (Fig. 3D). The proportion of water from tributaries made up $81 \%$ of the discharge at the river mouth during spring flood periods, but $18 \%$ during low-water periods. The seasonal patterns of dissolved Mn, Fe and Al (Fig. 6) at the mouth of the SLR were very similar to those of the water sources (Fig. 7). The relationships between dissolved Mn and the proportion of water from tributaries were highly significant (correlation coefficients of 0.72 ). The key factors accounting for seasonality at the river mouth were the large differences in the concentrations for the dissolved minor elements between the Ottawa River (higher) and the upper SLR (lower) and the hydrologic stability of the main flow from Lake Ontario as compared to the marked hydrologic regimes of tributaries. Unlike major elements (Fig. 2), dissolved Fe and Mn showed a dilution line influenced by seasonality for the tributaries. Fe and Mn concentrations in the Ottawa River show lower concentrations in summer and early fall than in winter and spring (Fig. 8), which correspond to the oxyhydroxides precipitation previously described. Low Fe and $\mathrm{Mn}$ concentrations are associated with high $\mathrm{Ca}$ in the upper SLR water (Fig. 8). The dilution of Ottawa River with upper SLR waters account for the intermediate concentrations measured at the mouth of the river (Fig. 8). Highest concentrations of dissolved Mn correspond to snow-melting during high discharge from south-shore tributaries in winter and spring.

\subsubsection{Trace elements (Cd, Co, Cu, Ni and $\mathrm{Zn})$}

Trace elements, unlike minor elements, showed no large difference between the two endmembers and consequently a slighter dilution effect. However, seasonality of trace metals at the river mouth could relate to that of source end-members. Dissolved $\mathrm{Zn}$ displayed a seasonal pattern similar to that of dissolved Mn (Fig. 6), i.e. associated with dilution of water masses with a larger monthly amplitude (Fig. 7). Dissolved $\mathrm{Cd}$, Ni and Co showed maximum values during winter, minimum values in summer and steadily increasing concentrations in fall. The seasonal 
pattern of $\mathrm{Cd}$ at the river mouth was the same than the upper St. Lawrence River. Dissolved $\mathrm{Cu}$ exhibited great variability in spring in relation to high flows of north- and south-shore tributaries.

Particulate Ni, Co and Zn concentrations were stable throughout the sampling period (Fig. 6) and did not exceed twice the values of the earth's crust (Table 2). These metals showed no relationship with SPM, and concentrations were very similar to those found in material eroded from the bed and banks of the river (Table 2), which constitute a large part of the suspended load at the river mouth (Rondeau et al., 2000). Particulate $\mathrm{Cu}$ and $\mathrm{Cd}$ showed slightly higher values in winter when POC content at the river mouth was maximum.

\subsection{Mass balances}

The relative importance of the main metal sources in the St. Lawrence was estimated by a mass balance budget in the sector stretching from Cornwall to Quebec City for the 1995-1996 period. This budget was based on flux estimates derived from samples collected during that period and from published loads (Table 3). The calculations (Appendix 1) involved high-frequency data concerning the main discharges (upper St. Lawrence, Ottawa River and Quebec City) and lower frequency measurements in sources of lesser importance (the St. Maurice, Richelieu, St. François, Yamaska and Nicolet Rivers). Load estimates for the origin of industrial, municipal, atmospheric and eroded sediment origin were previously published values (see the caption of Table 3).

The budget summarizes the relative importance of metal sources in the river. The Lake Ontario, which provides most of the discharge to the river (>60\%), are also the main source of dissolved trace elements, but a small source of minor elements $(<20 \%)$. As expected because of the very low SPM concentrations in the upper St. Lawrence River, the Lake Ontario constitutes a minor source of particulate metals, representing less than $5 \%$ of the load to the SLR. The Ottawa River and other tributaries are major sources of dissolved and particulate metals to the SLR $(\sim 40 \%)$. Particulate 
matter contributed more than $80 \%$ of the load at the mouth of the river for $\mathrm{Al}, \mathrm{Fe}, \mathrm{Mn}, \mathrm{Co}$, and $\mathrm{Zn}$ and more than $50 \%$ for the other elements in this study. With the exception of $\mathrm{Cd}$ and $\mathrm{Zn}$, more than $80 \%$ of the total and dissolved load of metals at the outlet of the SLR can be explained by the different sources considered. Within the estimated uncertainty, the budget of all dissolved elements, except $\mathrm{Fe}$ and $\mathrm{Zn}$, was balanced, as was the budget of particulate elements, except $\mathrm{Cd}$ and $\mathrm{Zn}$. The main sources of metals to the River are erosion, tributaries and the Lake Ontario. The budget is not balanced for Fe because of missing tributary data and shows an output surplus of $\mathrm{Cd}$ and $\mathrm{Zn}$, which can only be attributed to unidentified internal sources.

The metal budget closely reflects the water and suspended sediment budget and is consistent with seasonal variations observed at the river mouth. The amounts of metals at the river mouth are strongly governing by dilution effects of waters from the Lake Ontario (dissolved minor elements) and erosion (particulate elements). With the exception of $\mathrm{Cd}$ and $\mathrm{Zn}$, these amounts are mainly attributable (30 to 50\%) to marine clays eroded from the bed and banks of the St. Lawrence, constitute the largest component of the river sediment budget (Rondeau et al., 2000) and makes a significant contribution to the metal loads transported by the river.

Metals known to be rejected directly to the river by anthropogenic sources accounted for less than 5\% of the load observed at Quebec City, except for Cd rejects that comprise $10 \%$ of the load. An important fraction (16\%) of the $\mathrm{Zn}$ comes from atmospheric sources directly into the river, while $21 \%$ is left unexplained and is suspected to be attributable to anthropic (unknown) sources. 


\section{SUMMARY AND CONCLUSIONS}

The chemistry of river water is controlled primarily by the weathering of different lithologies and their related soils and biomass, and secondarily by anthropic inputs. The longer residence time of waters in Lake Ontario than other water sources of the St. Lawrence River promotes the metal impoverishment in the dissolved phase of the water column as a result of metal scavenging by particles and their subsequent sedimentation. Indeed, metal concentrations in the upper St. Lawrence River are generally lower than in the tributaries and the input of particulate metals is negligible (load $<5 \%$ ). The Ottawa River is representative of the north-shore tributaries that drain areas of crystalline rock and forest cover in most catchment basins and show high dissolved metal concentrations (with the exception of $\mathrm{Ni}$ ) promoted by their complexation with organic matter. The south-shore tributaries exhibit some high metal concentrations, possibly due to anthropogic activities in their basins. With the exception of these tributaries, dissolved metal concentrations in the SLR are comparable to levels found in only slightly contaminated bodies of water and often approached «pristine» levels (Table 2). Recorded anthropic sources accounted for less than $5 \%$ of the load observed at the river mouth, except for Cd rejects that comprise $10 \%$ of the load. Moreover, $21 \%$ of the $\mathrm{Zn}$ load is unexplained and probably attributable to unidentified anthropic sources. Particulate metals, with the exception of $\mathrm{Zn}$, are relatively low and coming close to values for the earth's crust during floods and especially at the river mouth where inorganic particles from erosion of the SLR bed and banks constitute more than $45 \%$ of the SPM and metals load.

The interaction between hydrological cycles and chemistry controls seasonality. This classical paradigm applies to the different waters masses of the SLR studied here. Several biogeochemical and hydrodynamical processes occurring in Lake Ontario drive the seasonal variations of minor 
and trace elements observed in the upper St. Lawrence River: the biogeochemistry processes consist of biological uptake, regeneration of organic matter ( $\mathrm{Cd}$ and $\mathrm{Zn})$ and oxyhydroxide formation ( $\mathrm{Mn}$ and $\mathrm{Fe}$ ); the hydrodynamic processes relate mainly to seasonal change in the vertical stratification in Lake Ontario $(\mathrm{Cd}, \mathrm{Mn}, \mathrm{Zn})$. In the Ottawa River, oxyhydroxide formation in warm seasons governs many seasonal patterns for metals, namely $\mathrm{Al}, \mathrm{Fe}, \mathrm{Mn}, \mathrm{Cd}$, $\mathrm{Co}$ and $\mathrm{Zn}$. At the river mouth, seasonal variations of minor elements are driven by dilution effects. High concentrations of dissolved metals from tributaries ( $>60 \%$ of the loads) are diluted by large amount of water from lake Ontario containing lower concentration $(<15 \%$ of the loads). For dissolved trace metals, seasonal variations reflect biogeochemical and hydrodynamic processes observed at the two end-members. Trace metal concentrations in the upper SLR are generally lower than in tributaries, but loads are quite similar. Particulate metals at the river mouth are highly governed by dilution effects due to large inputs of inorganic particles from erosion of the SLR bed and banks.

Acknowledgments-- This research was supported by the St. Lawrence Action Plan, SLV-2000. The authors are grateful to M. Arseneau, J.-F. Hélie, B. Isernhagen, D. Labonté, D. Many, and P. Turcotte for assistance during sampling and in the laboratory, and to Chi Tran (Montreal University) and C. Gobeil (Fisheries and Oceans Canada), who allowed the use of their ICP-MS facilities. Thanks are due to J. Carignan and an unknown reviewer for constructive criticisms that helped improve the paper. 


\section{REFERENCES}

Bobée, B., Lachance, M., Potvin, L., 1980. Analyse multivariée et interprétation géochimique de la variabilité spatiale de la qualité de l'eau des rivières du Québec méridional. J. Hydrol., 53, 95-116.

Bergeron, M., Poissant, P. 2000. Contribution relative de l'atmosphère à la masse toxique transportée par le fleuve Saint-Laurent. Section sur les processus atmosphérique des toxiques, Environnement Canada, région du Québec, 38 p.

Cossa, D., 1990. Chemical contaminants in the St. Lawrence Estuary and Saguenay Fjord. P. 240-268. Chap. 11. In : Oceanography of a Large-Scale Estuarine System : The St.Lawrence. El-Sabh, M.I. Silverberg, N. (Eds.) Springer-Verlag, N.Y. 434 pp.

Cossa, D., Tremblay, G.H., Gobeil, C., 1990. Seasonality in iron manganese concentrations of the St. Lawrence River. Sci. Total Environ., 97/98, 185-190.

Cossa, D., Rondeau B., Pham, T.T., Proulx, S., Quémerais, B., 1996. Principes et pratiques d'échantillonnage d'eaux naturelles en vue du dosage de substances et d'éléments présents à l'état de traces et ultra-traces. Environnement Canada - Région du Québec, Conservation de l'environnement, Centre Saint-Laurent. Document de travail DT-5, 28 pages.

Cossa, D., Pham, T.T., Rondeau, B., Quémerais, B., Proulx, S., Surette, C., 1998. Bilan massique des contaminants chimiques dans le fleuve Saint-Laurent, Environnement Canada - Région du Québec, Conservation de l'environnement, Centre Saint-Laurent. Rapport scientifique et technique ST-163, $258 \mathrm{p}$. 
Deschamps, G., Juteau, C., Cejka, P.J., 1998. Évolution des contaminants toxiques dans les eaux usées à la station d'épuration de la Communauté urbaine de Montréal en 1995 et 1996. Communauté urbaine de Montréal, Service de l'environnement, Réseau de Suivi Écologique. RSÉ 98-01. 50 p.98

Duan, N., 1983. Smearing estimate: a nonparametric retransformation method. J. American Statistical Association, 78, 605-610.

Dumouchel, F., Turcotte, P., Surette, C., Jobin, J., 1998. Méthode d'analyse d'éléments métalliques majeurs, mineurs et traces dans les phases dissoute et particulaire des eaux naturelles. Environnement Canada - Région du Québec, Conservation de l'environnement, Centre Saint-Laurent. Rapport scientifique et technique ST-122, 23 p.

Dupré, B., Gaillardet, J., Rousseau, D., Allègre, C.J., 1996. Major and trace elements of riverborne material: The Congo Basin. Geochim. Cosmochim. Acta, 60, 1301-1321.

Frenette, M., Barbeau, C., Verrette, J.L., 1989. Aspects quantitatifs, dynamiques et qualitatifs des sédiments du Saint-Laurent. Hydrotech Consultants Inc., for Environment Canada and the Government of Quebec.

Gilroy, E.J., Hirsch, R.M., Cohn, T.A., 1990. Mean square error of regression-based constituent transport estimates. Water Res. Research, 26, 2069-2077.

Janson, M., Sloterdijk, H., 1982. Données sur la qualité des eaux de surface, Fleuve SaintLaurent, Québec 1950-1980. Environnement Canada, Direction générale des eaux intérieures, Section des relevés de qualité, Région du Québec.

Lalonde, J.D., Amyot, M., Kraepiel, A.M.L., Morel, F.M.M., 2001. Photooxidation of $\operatorname{Hg}(0)$ in Artificial and Natural Waters. Environ. Sci. Technol., 35: 1367-1372. 
Lum, K.R., 1987. Cadmium in fresh waters: the Great Lakes and St. Lawrence River. In: Nriagu, J.O. Sprage, J.B. (Eds.), Cadmium in the aquatic environment. Wiley series vol. 19, pp. 3550.

Mantoura, R.F.C., Dickson, A., Riley, J.P., 1978. The complexation of metals with humic materials in natural waters. Est. Cstl. Mar. Sci., 6, 387-408.

Meybeck, M., Pasco, A., Ragu, A., 1992. Établissement des flux polluants dans les rivières. Étude Inter-agences No 28, Agences de l'Eau/Minsitère de l'Environnement, Paris.

Nriagu, J.O., G. Lawson, G., Wong, H.V.T., Cheam, V., 1996. Dissolved trace metals in lakes Superior, Erie, and Ontario. Environ. Sci. Technol., 30, 178-187.

Pocklington, R., 1982. Carbon transport in major world rivers: the St Lawrence, Canada. In: Degens, E.T., Kempe, S. Soliman, H (Eds.). Transport of Carbon and minerals in major World Rivers, Part. 2. Mitt. Geol.- Palaont. Inst. Univ. Hamburg, SCOPE/UNEP Sonderbd. 55, pp. $145-51$.

Ponter, C., Ingri, J., Bostrom, K., 1992. Geochemistry of manganese in the Kalix River, northern Sweden. Geochim. Cosmochim. Acta, 56, 485-1494.

Quémerais, B., Lum, K., 1997. Distribution and temporal variation of cadmium in the St.Laurence River basin. Aquat. Sci., 59, 243-259.

Quémerais, B., Cossa, D., Rondeau, B., Pham, T.T., Fortin, B., 1998. Mercury distribution in relation to iron and manganese in the waters of the St. Lawrence river. Sci. Total Environ., 213, 193-201.

Quémerais, B., Cossa, D., Rondeau, B., Pham, T.T., Gagnon, P., Fortin B., 1999. Sources and fluxes of Mercury in the St. Lawrence River. Environ. Sci. Technol., 33, 840-849. 
Rondeau, B., Cossa, D., Gagnon, P., Bilodeau, L., 2000. Sources of suspended sediments transported in the St. Lawrence River. Hydrol. Proc., 14, 21-36.

Rondeau, B., 1998. Validation d'une station de référence pour le suivi de la qualité des eaux dans le Saint-Laurent à Québec. Environnement Canada - Région du Québec, Conservation de l'environnement, Centre Saint-Laurent. Rapport scientifique et technique ST-175, 58 pages.

Rondeau, B., 1993. Qualité des eaux du fleuve Saint-Laurent 1985-1990, tronçon Cornwall-Québec. Environnement Canada, Conservation et protection, Centre Saint-Laurent, 250 p.

Rudnick, R.L., Gao, S. 2003. Composition of the Continent Crust. In: Treatise on Geochemistry. Holland, H.D., Turekian, K.K. eds. Vol. 3: The Crust, Rudnick, R.L. ed. Elsevier-Pergamon, 7800 p.

Seyler, P., Elbaz-Poulichet, F., 1996. Biogeochemical control on the temporal variability of trace element concentrations in the Oubangui river (Central African Republic). J. Hydrol., 180, 319-332.

Shiller, A.M., 1997 Dissolved trace elements in the Mississippi River: Seasonal, interannual, and decadal variability. Geochim. Cosmochim. Acta, 61, 4321-4330.

Simonetti, A., Gariépy, C., Carignan, J., 2000. Pb and Sr isotopic compositions of snowpack from Québec, Canada: inferences on the sources and deposition budgets of atmospheric heavy metals. Geochim. Cosmochim. Acta 64 : 5-20.

Stumm, W., Morgan, J. J., 1996. Aquatic Chemistry. Wiley, New-York, N.-Y., 780 p.

Tremblay, G.H., Cossa, D., 1987. Major ion composition of the St. Lawrence River : variations since the start of industrialisation. In: Degens, E. T., Kempe, S. Weibin, G. (Eds.). Transport 
of Carbon and Minerals in Major World Rivers. Part 4, SCOPE/UNEP Carbon Unit, Hamburg University, Germany, pp. 289-294.

U.S. EPA, 1984. Guidelines establishing test procedures for the analysis of pollutants under the clean water act : final rule and proposed rule. Federal Register, Part VIII, EPA 40 CFR Part 136.

Yang, C., Telmer, K., Veizer, J., 1996. Chemicals dynamics of the St. Lawrence riverine system: $\delta \mathrm{D}_{\mathrm{H} 2 \mathrm{O}}, \delta^{18} \mathrm{O}_{\mathrm{H} 2 \mathrm{O}}, \delta^{13} \mathrm{C}_{\mathrm{DIC}}, \delta^{34} \mathrm{~S}_{\text {sulfate }}$, and dissolved ${ }^{87} \mathrm{Sr} /{ }^{86} \mathrm{Sr}$. Geochim. Cosmochim. Acta, 60, $851-866$. 


\section{APPENDIX: METAL FLUXES CALCULATIONS}

\section{Dissolved metals}

\section{Sampled fluxes}

Dissolved metal loads were calculated as averages, weighed by flow $\left(\mathrm{F}_{4}\right.$ from Meybeck, 1992) :

$$
C Q=\frac{\sum_{i} Q_{i} C_{i}}{\sum_{i} Q_{i}} Q_{t}
$$

Where $C_{i}$ and $Q_{i}$ are sampled concentrations and discharges respectively, and $Q_{t}$ is the total flow for the whole year. Standard error estimations neglect flow measurement errors and assume independence between concentration measurements :

$$
S E(C Q)=\frac{Q_{t}}{\sum_{i} Q_{i}} \sqrt{\sum_{i} Q_{i}^{2} \operatorname{Var}(C)}
$$

This last assumption was not entirely met in cases where most samples were taken during the spring freshet. This may have led to an underestimation of the error for these cases. On the other hand, the concentration variance is greater during that time of the year, thus the combined effect of the sampling plan and our estimation method probably yields fairly conservative dissolved load estimate errors.

\section{Unsampled tributaries}

The dissolved metal contribution to the budget from smaller rivers was estimated from the overall specific yield of sampled tributaries located on the same shore. Variance estimates from sampled rivers were multiplied by factors reflecting these extra contributions to the budget.

\section{Particulate metals}

The metal flux carried by suspended particles increases almost proportionally with the concentration of suspended matter. The composition of the particles may also vary, as the relative contributions from various erosion sources change with hydrological conditions. The simple load estimation models that follow attempt to capture both phenomena together. 
Most relationships were modeled by power functions. The model parameters were estimated by least squares on the log scale and back-transformed to the original scale with the smearing estimate correction (Duan, 1983). Standard error calculations on the loads derived from these models followed Gilroy et al., 1990.

\section{Sampled fluxes}

When enough data was available, the relationship between metal concentration in water and flow was established by regression, daily values were calculated from known discharge rates, and the corresponding fluxes were summed over the entire year. Otherwise, the loads were estimated as weighed averages, in the same way as for dissolved metals. Iron and copper in the Yamaska River were special cases. The load estimates for these two metals were established using their average concentration in the SPM because the relationship between water concentration and discharge was very much influenced by one of the four SPM observations available.

Table 1. Power models for estimating the metal concentration carried by SPM from discharge expressed in $m^{3} s^{-1}$. See text for $\mathrm{F}_{4}$ equation.

\begin{tabular}{|c|c|c|c|c|c|c|c|c|c|c|c|c|c|c|c|c|}
\hline & \multicolumn{2}{|c|}{$\mathrm{Al}(\mu \mathrm{mol} / \mathrm{l})$} & \multicolumn{2}{|c|}{$\mathrm{Fe}(\mu \mathrm{mol} / \mathrm{l})$} & \multicolumn{2}{|c|}{$\mathrm{Mn}(\mu \mathrm{mol} / \mathrm{l})$} & \multicolumn{2}{|c|}{ Co (nmol/l) } & \multicolumn{2}{|c|}{$\mathrm{Cd}(\mathrm{pmol} / \mathrm{l})$} & \multicolumn{2}{|c|}{$\mathrm{Cu}(\mathrm{nmol} / \mathrm{l})$} & \multicolumn{2}{|c|}{$\mathrm{Ni}(\mathrm{n} \mathrm{mol} / \mathrm{l})$} & \multicolumn{2}{|c|}{$\mathrm{Zn}(\mathrm{nmol} / \mathrm{l})$} \\
\hline & exponent & factor & exponent & factor & exponent & factor & exponent & factor & exponent & factor & exponent & factor & exponent & factor & exponent & factor \\
\hline Nicolet & 1.05 & 0.90 & 0.90 & 0.58 & 0.91 & 0.0118 & 0.95 & 0.15 & 0.79 & 3.09 & 0.74 & 0.87 & $\mathrm{~F}_{4}$ & & $\mathrm{~F}_{4}$ & \\
\hline Richelieu & 1.72 & 0.0011 & 1.61 & 0.0007 & 1.46 & $4 \mathrm{E}-05$ & 1.91 & 4E-05 & 1.10 & 0.0922 & 1.56 & 0.0008 & $\mathrm{~F}_{4}$ & & $\mathrm{~F}_{4}$ & \\
\hline Saint-François & 1.26 & 0.0272 & 1.15 & 0.0174 & 1.11 & 0.0006 & 1.23 & 0.0033 & 0.94 & 0.54 & 0.95 & 0.0554 & $\mathrm{~F}_{4}$ & & NA & \\
\hline Saint-Maurice & $\mathrm{F}_{4}$ & & $\mathrm{~F}_{4}$ & & $\mathrm{~F}_{4}$ & & $\mathrm{~F}_{4}$ & & $\mathrm{~F}_{4}$ & & $\mathrm{~F}_{4}$ & & $\mathrm{~F}_{4}$ & & $\mathrm{~F}_{4}$ & \\
\hline Yamaska & 1.13 & 0.66 & Averag & $e^{(1)}$ & $\mathrm{F}_{4}$ & & 0.88 & 0.27 & 0.93 & 1.95 & Averag & $\mathrm{e}^{(1)}$ & NA & & $\mathrm{F}_{4}$ & \\
\hline Ottawa & 1.07 & 0.0062 & 0.97 & 0.005 & 0.59 & 0.0028 & 1.07 & 0.0007 & 0.88 & 0.13 & 1.02 & 0.0019 & 1.02 & 0.0045 & 0.92 & 0.0267 \\
\hline Great Lakes & 1.10 & 0.0001 & 1.41 & 2E-06 & 1.26 & $2 \mathrm{E}-07$ & 2.42 & $6 \mathrm{E}-11$ & 3.39 & $7 \mathrm{E}-13$ & 1.06 & $6 \mathrm{E}-05$ & 0.46 & 0.0156 & -1.59 & $7 \mathrm{E}+06$ \\
\hline Québec & 1.91 & $8 \mathrm{E}-07$ & 1.69 & 2E-06 & 1.32 & $2 \mathrm{E}-06$ & 1.84 & $2 \mathrm{E}-07$ & 1.67 & $2 \mathrm{E}-05$ & 1.81 & 4E-07 & 1.76 & 1E-06 & 1.65 & $1 \mathrm{E}-05$ \\
\hline
\end{tabular}

${ }^{1)}$ Average metal concentration in SPM is multiplied by SPM load

\section{Unsampled tributaries}

The SPM metal contribution from unsampled rivers was estimated by assuming that their specific yield was the same as neighboring rivers. On the North shore, the overall specific yield of the Ottawa and SaintMaurice Rivers was taken to represent other rivers. On the South shore, the Châteauguay and Chaudière Rivers were assumed to have the same specific yield as the Saint-François River whereas other small tributaries were assumed to resemble the Nicolet and Yamaska Rivers. 


\section{Suspended matter}

The suspended particulate matter (SPM) budget was calculated from rating curves at all sources and from daily turbidity measurements at the mouth of the River (Table 2). The contribution from smaller tributaries was set to $30 \mathrm{t} \mathrm{yr}^{-1} \mathrm{~km}^{-2}$, with a $\mathrm{CV}$ of $25 \%$.

Table 2. Rating curve parameters (corrected) for predicting suspended particulate matter (SPM) concentration in $\mathrm{mg} \mathrm{l}^{-1}$ from discharge in $\mathrm{m}^{3} \mathrm{~s}^{-1}$.

\begin{tabular}{lrrl}
\hline \multicolumn{1}{c}{ River } & Exponent & Factor & Condition \\
\hline Nicolet & 0 & 5.04 & discharge $<40 \mathrm{~m} 3 / \mathrm{s}$ \\
& 1.29 & 0.083 & discharge $>=40 \mathrm{~m} 3 / \mathrm{s}$ \\
Richelieu & 0.60 & 0.55 & from $10-04$ to $13-12$ \\
& 2.00 & 0.00008 & from $14-12$ to $09-04$ \\
Saint-François & 0.52 & 1.26 & \\
Saint-Maurice & 0.98 & 0.0068 & \\
Yamaska & 0 & 62.67 & from $19-06$ to $16-10$ \\
& 0.86 & 0.78 & from $17-10$ to $18-06$ \\
Ottawa & 1.05 & 0.0022 & \\
Great Lakes & 0 & 1.40 & from $20-05$ to $19-11$ \\
& 0 & 0.47 & from $20-12$ to $19-05$ \\
Québec (1) & 1.15 & 0.87 & \\
Assomption & 0 & 17.01 & from $14-07$ to $06-10$ \\
& 0.78 & 0.72 & from $07-10$ to $13-07$ \\
Batiscan & 0.84 & 0.16 & \\
Sainte-Anne & 0.63 & 1.26 & \\
Jacques-Cartier & 0 & 4.46 & discharge $<100 \mathrm{~m} 3 / \mathrm{s}$ \\
& 0.06 & -3.76 & discharge $>=100 \mathrm{~m} 3 / \mathrm{s}$ \\
Châteauguay & 0 & 8.99 & discharge $<50 \mathrm{~m} 3 / \mathrm{s}$ \\
Chaudière & 1.16 & 0.10 & discharge $>=50 \mathrm{~m} 3 / \mathrm{s}$ \\
& 0.68 & 0.46 & discharge $<250 \mathrm{~m} 3 / \mathrm{s}$ \\
& 1.04 & 0.066 & discharge $>=250 \mathrm{~m} 3 / \mathrm{s}$ \\
\hline
\end{tabular}

(1) Rating curve is applied to turbidity measures in NTU.

${ }^{(2)}$ Slope and intercept of linear relationship. 


\section{TABLES}

Table 1. Hydrologic and mean chemical characteristics of the main water masses of the St. Lawrence River System.

\begin{tabular}{|c|c|c|c|c|}
\hline & $\begin{array}{l}\text { Upper St. Lawrence } \\
\text { River (Cornwall) }\end{array}$ & $\begin{array}{c}\text { North-shore } \\
\text { tributaries }\end{array}$ & $\begin{array}{c}\text { South-shore } \\
\text { tributaries }\end{array}$ & $\begin{array}{l}\text { River mouth } \\
\text { (Quebec City) }\end{array}$ \\
\hline \multicolumn{5}{|c|}{ Hydrological features } \\
\hline Drainage basin $\left(\mathrm{km}^{2}\right)$ & $7.7 \times 10^{5}$ & $2.1 \times 10^{5}$ & $0.6 \times 10^{5}$ & $10.3 \times 10^{5}$ \\
\hline Annual mean water discharge $\left(\mathrm{m}^{3} \mathrm{sec}^{-1}\right)$ & 7370 & 3100 & 1060 & 12600 \\
\hline Seasonal amplitude $\left(\mathrm{m}^{3} \mathrm{sec}^{-1}\right)$ & 3400 & 8200 & 7200 & 14200 \\
\hline $\begin{array}{l}\text { Annual mean suspended particulate } \\
\text { matter }\left(\mathrm{mg} \mathrm{L}^{-1}\right)\end{array}$ & 1 & 7.1 & 24.8 & 17 \\
\hline Specific sediment yield (ton $\mathrm{km}^{-2} \mathrm{yr}^{-1}$ ) & 0.3 & 4.1 & 17.9 & 6.7 \\
\hline Suspended particle flux $\left(10^{3}\right.$ tons $\left.\mathrm{yr}^{-1}\right)$ & 200 & 900 & 1300 & $6900^{\mathrm{a}}$ \\
\hline \multicolumn{5}{|c|}{ Chemical characteristics } \\
\hline $\mathrm{Na}^{+}\left(\mathrm{mEq} \mathrm{L}{ }^{-1}\right)$ & 0.48 & 0.14 & 0.50 & 0.43 \\
\hline $\mathrm{K}^{+}\left(\mathrm{mEq} \mathrm{L}^{-1}\right)$ & 0.04 & 0.01 & 0.04 & 0.03 \\
\hline $\mathrm{Ca}^{2+}\left(\mathrm{mEq} \mathrm{L}^{-1}\right)$ & 1.74 & 0.34 & 0.99 & 1.36 \\
\hline $\mathrm{Mg}^{2+}\left(\mathrm{mEq} \mathrm{L}^{-1}\right)$ & 0.68 & 0.14 & 0.36 & 0.53 \\
\hline $\mathrm{Cl}^{-}\left(\mathrm{mEq} \mathrm{L}^{-1}\right)$ & 0.62 & 0.17 & 0,57 & 0.48 \\
\hline $\mathrm{SO}^{2-}\left(\mathrm{mEq} \mathrm{L}^{-1}\right)$ & 0.57 & 0.16 & 0.38 & 0.47 \\
\hline Total alkalinity $\left(\mathrm{mEq} \mathrm{L}^{-1}\right)$ & 1.47 & 0.33 & 0.87 & 1.3 \\
\hline Conductivity $\left(\mu \mathrm{S} \mathrm{cm}^{-1}\right)$ & 298 & 73 & 203 & 229 \\
\hline $\mathrm{pH}$ & 7.7 & 6.8 & -- & 7.6 \\
\hline DOC $\left(\mu \mathrm{mol} \mathrm{L}{ }^{-1}\right)$ & 209 & 512 & --- & 298 \\
\hline $\mathrm{POC}\left(\mathrm{mmol} \mathrm{g}^{-1}\right)$ & 24.8 & 7.0 & 5.0 & 3.7 \\
\hline
\end{tabular}

Hydrological data are from Rondeau et al. (2000), and chemical data are from Cossa et al. (1998) and Yang et al. (1996). Tributaries data are weighted means for the following rivers: Ottawa, St. Maurice, L'Assomption, Batiscan, St. Anne and Jacques Cartier, which represent $96 \%$ of the north-shore water flow; and Chateauguay, Richelieu, St. François, Yamaska, Nicolet and Chaudière, which represent $95 \%$ of the south-shore tributaries. (a) $65 \%$ of the suspended particles outflowing at Quebec City originate from erosion of the SLR bed and banks (Rondeau et al., 2000). 

Table 2. Summary statistics for minor and trace element concentrations in water $\left(\mathrm{D} ; \mathrm{nmol} \mathrm{L}{ }^{-1}\right)$ and suspended particles $\left(\mathrm{P} ; \mu\right.$ mol $\left.\mathrm{g}^{-1}\right)$ of the St. Lawrence River and its tributaries (mean \pm SD, No. of samples in parentheses ) and measured values for reference water and sediment reference material.

\begin{tabular}{|c|c|c|c|c|c|c|c|c|c|c|c|c|c|c|c|c|}
\hline & \multicolumn{2}{|c|}{$\mathrm{Al}$} & \multicolumn{2}{|c|}{$\mathrm{Fe}$} & \multicolumn{2}{|c|}{$\mathrm{Mn}$} & \multicolumn{2}{|r|}{$\mathrm{Cd}$} & \multicolumn{2}{|c|}{$\mathrm{Cu}$} & \multicolumn{2}{|c|}{$\mathrm{Ni}$} & \multicolumn{2}{|c|}{$\mathrm{Zn}$} & \multicolumn{2}{|c|}{ Co } \\
\hline & $\mathrm{D}$ & $\mathrm{P}$ & $\mathrm{D}$ & $\mathrm{P}$ & $\mathrm{D}$ & $\mathrm{P}$ & $\mathrm{D}$ & $\mathrm{P}$ & $\mathrm{D}$ & $\mathrm{P}$ & $\mathrm{D}$ & $\mathrm{P}$ & $\mathrm{D}$ & $\mathrm{P}$ & $\mathrm{D}$ & $\mathrm{P}$ \\
\hline Upper St. Lawrence & & & & & & & & & & & & & & & & \\
\hline Cornwall & $\begin{array}{l}<74 \\
(35)\end{array}$ & $\begin{array}{l}1980 \pm 430 \\
\quad(39)\end{array}$ & $\begin{array}{c}72 \pm 36 \\
(39)\end{array}$ & $\begin{array}{c}620 \pm 110 \\
(39)\end{array}$ & $\begin{array}{c}28 \pm 12 \\
(39)\end{array}$ & $\begin{array}{l}18.3 \pm 8.0 \\
\quad(39)\end{array}$ & $\begin{array}{c}0.07 \pm 0.04 \\
(34)\end{array}$ & $\begin{array}{c}0.0100 \pm 0.0077 \\
(38)\end{array}$ & $\begin{array}{l}10.4 \pm 1.1 \\
(39)\end{array}$ & $\begin{array}{c}0.73 \pm 0.25 \\
\quad(32)\end{array}$ & $\begin{array}{l}11.2 \pm 1.3 \\
(35)\end{array}$ & $\begin{array}{c}0.92 \pm 0.24 \\
(28)\end{array}$ & $\begin{array}{l}4.6 \pm 2.0 \\
(27)\end{array}$ & $\begin{array}{l}5.6 \pm 2.7 \\
(29)\end{array}$ & $\begin{array}{c}0.87 \pm 0.09 \\
(37)\end{array}$ & $\begin{array}{l}0.14 \pm 0.05 \\
\text { (39) }\end{array}$ \\
\hline North-shore tributaries & & & & & & & & & & & & & & & & \\
\hline Ottawa & $\begin{array}{c}726 \pm 297 \\
(48)\end{array}$ & $\begin{array}{l}2740 \pm 380 \\
\quad(68)\end{array}$ & $\begin{array}{c}665 \pm 227 \\
(43)\end{array}$ & $\begin{array}{c}1050 \pm 100 \\
(64)\end{array}$ & $\begin{array}{c}106 \pm 64 \\
(51)\end{array}$ & $\begin{array}{c}34.0 \pm 18.6 \\
(64)\end{array}$ & $\begin{array}{c}0.09 \pm 0.05 \\
\quad(45)\end{array}$ & $\begin{array}{c}0.0156 \pm 0.0097 \\
(68)\end{array}$ & $\begin{array}{l}13.8 \pm 2.6 \\
\quad(51)\end{array}$ & $\begin{array}{c}0.59 \pm 0.09 \\
(64)\end{array}$ & $\begin{array}{c}7.6 \pm 2.3 \\
(43)\end{array}$ & $\begin{array}{c}1.39 \pm 0.45 \\
(68)\end{array}$ & $\begin{array}{l}9.0 \pm 5.1 \\
(48)\end{array}$ & $\begin{array}{c}3.9 \pm 1.3 \\
\quad(63)\end{array}$ & $\begin{array}{c}0.77 \pm 0.32 \\
(43)\end{array}$ & $\begin{array}{c}0.31 \pm 0.04 \\
(63)\end{array}$ \\
\hline St. Maurice 2 & $\begin{array}{c}2300 \pm 1280 \\
(7)\end{array}$ & $\begin{array}{c}2100 \pm 40 \\
(4)\end{array}$ & & $\begin{array}{c}1400 \pm 120 \\
(4)\end{array}$ & $\begin{array}{c}200 \pm 154 \\
(7)\end{array}$ & $\begin{array}{l}29.0 \pm 5.0 \\
(4)\end{array}$ & & $\begin{array}{c}0.0110 \pm 0.0064 \\
\text { (6) }\end{array}$ & $\begin{array}{l}11.1 \pm 7.9 \\
\text { (7) }\end{array}$ & $\begin{array}{c}0.4 \pm 0.03 \\
(4)\end{array}$ & $\begin{array}{c}10.9 \pm 3.3 \\
\text { (7) }\end{array}$ & $0.4 \underset{(3)}{ \pm 0.03}$ & & $\begin{array}{l}4.7 \pm 1.1 \\
\quad(3)\end{array}$ & $\begin{array}{c}1.2 \pm 0.11 \\
(3)\end{array}$ & $\begin{array}{c}0.2 \pm 0.05 \\
(4)\end{array}$ \\
\hline South-shore tributaries & & & & & & & & & & & & & & & & \\
\hline Richelieu & $\begin{array}{c}512 \pm 179 \\
(9)\end{array}$ & $\begin{array}{l}2750 \pm 280 \\
(26)\end{array}$ & & $\begin{array}{l}900 \pm 90 \\
(26)\end{array}$ & $\begin{array}{c}33 \pm 13 \\
(9)\end{array}$ & $\begin{array}{l}21.5 \pm 5.1 \\
(26)\end{array}$ & & $\begin{array}{c}0.0065 \pm 0.0037 \\
(35)\end{array}$ & $\begin{array}{c}13.9 \pm 3.0 \\
(9)\end{array}$ & $\begin{array}{l}0.82 \pm 0.28 \\
\quad(35)\end{array}$ & $\begin{array}{c}6.3 \pm 2.2 \\
(9)\end{array}$ & $\begin{array}{c}1.18 \pm 0.26 \\
(12)\end{array}$ & $\begin{array}{l}9.0 \pm 1.8 \\
(9)\end{array}$ & $\begin{array}{l}2.9 \pm 0.6 \\
\quad(7)\end{array}$ & $\begin{array}{c}1.41 \pm 0.66 \\
(9)\end{array}$ & $\begin{array}{c}0.32 \pm 0.12 \\
(35)\end{array}$ \\
\hline St. François & $\begin{array}{c}978 \pm 255 \\
(9)\end{array}$ & $\begin{array}{l}2760 \pm 230 \\
(16)\end{array}$ & & $\begin{array}{l}900 \pm 70 \\
(16)\end{array}$ & $\begin{array}{l}373 \pm 347 \\
(9)\end{array}$ & $\begin{array}{c}26.9 \pm 6.9 \\
(16)\end{array}$ & & $\begin{array}{c}0.0077 \pm 0.0025 \\
(17)\end{array}$ & $\begin{array}{c}27.8 \pm 3.7 \\
(9)\end{array}$ & $\begin{array}{l}0.88 \pm 0.19 \\
(16)\end{array}$ & $\begin{array}{l}35.3 \pm 3.9 \\
(9)\end{array}$ & $\begin{array}{c}1.44 \pm 0.18 \\
\text { (4) }\end{array}$ & $\begin{array}{l}13.8 \pm 3.7 \\
(9)\end{array}$ & & $\begin{array}{l}1.61 \pm 0.63 \\
(9)\end{array}$ & $\begin{array}{l}0.28 \pm 0.05 \\
\quad(17)\end{array}$ \\
\hline Yamaska & $\begin{array}{c}974 \pm 125 \\
\quad(8)\end{array}$ & $\begin{array}{l}3160 \pm 230 \\
(18)\end{array}$ & & $\begin{array}{c}1010 \pm 50 \\
\text { (4) }\end{array}$ & $\begin{array}{l}294 \pm 61 \\
(6)\end{array}$ & $\begin{array}{c}18.8 \pm 6.5 \\
(4)\end{array}$ & & $\begin{array}{c}0.0034 \pm 0.0010 \\
(18)\end{array}$ & $\begin{array}{l}26.8 \pm 4.8 \\
(8)\end{array}$ & $\begin{array}{l}0.68 \pm 0.06 \\
\quad(4)\end{array}$ & $\begin{array}{l}22.1 \pm 3.0 \\
(8)\end{array}$ & & $\begin{array}{l}19.6 \pm 8.1 \\
(8)\end{array}$ & & $\begin{array}{l}3.12 \pm 0.56 \\
\text { (7) }\end{array}$ & $\begin{array}{l}0.34 \pm 0.05 \\
(14)\end{array}$ \\
\hline Nicolet & $\begin{array}{c}1141 \pm 357 \\
(8)\end{array}$ & $\begin{array}{l}3150 \pm 210 \\
\quad(23)\end{array}$ & & $\begin{array}{l}1060 \pm 260 \\
(23)\end{array}$ & $\begin{array}{l}297 \pm 107 \\
(7)\end{array}$ & $\begin{array}{c}23.0 \pm 7.9 \\
(23)\end{array}$ & & $\begin{array}{c}0.0037 \pm 0.0021 \\
(23)\end{array}$ & $\begin{array}{l}16.0 \pm 2.1 \\
(8)\end{array}$ & $\begin{array}{l}0.71 \pm 0.39 \\
\quad(23)\end{array}$ & $\begin{array}{c}16.9 \pm 2.9 \\
(8)\end{array}$ & $\begin{array}{c}0.98 \pm 0.13 \\
(6)\end{array}$ & $\begin{array}{l}8.3 \pm 3.6 \\
(7)\end{array}$ & $\begin{array}{l}2.9 \pm 0.7 \\
\text { (3) }\end{array}$ & $\begin{array}{l}1.91 \pm 0.34 \\
\text { (8) }\end{array}$ & $\begin{array}{c}0.36 \pm 0.21 \\
(24)\end{array}$ \\
\hline Erosion $^{a}$ & & $\begin{array}{l}3300 \pm 220 \\
(7)\end{array}$ & & $\begin{array}{c}880 \pm 50 \\
\text { (7) }\end{array}$ & & $\begin{array}{l}15.0 \pm 0.7 \\
\text { (7) }\end{array}$ & & $\begin{array}{c}0.0014 \pm 0.0005 \\
(6)\end{array}$ & & $\begin{array}{l}0.75 \pm 0.02 \\
\quad(4)\end{array}$ & & $\begin{array}{l}1.04 \pm 0.05 \\
(6)\end{array}$ & & $\begin{array}{l}1.6 \pm 0.1 \\
(6)\end{array}$ & & $\begin{array}{c}0.37 \pm 0.05 \\
(6)\end{array}$ \\
\hline Earth crust ${ }^{b}$ & & 3022 & & 702 & & 14 & & 0.0080 & & 0.44 & & 0.80 & & 1.0 & & 0.29 \\
\hline Quebec & $\begin{array}{c}670 \pm 274 \\
(164)\end{array}$ & $\begin{array}{l}2780 \pm 400 \\
(178)\end{array}$ & $\begin{array}{l}357 \pm 164 \\
(165)\end{array}$ & $\begin{array}{l}950 \pm 130 \\
(181)\end{array}$ & $\begin{array}{c}98 \pm 67 \\
(156)\end{array}$ & $\begin{array}{l}24.5 \pm 6.2 \\
(179)\end{array}$ & $\begin{array}{l}0.10 \pm 0.05 \\
\quad(115)\end{array}$ & $\begin{array}{c}0.0068 \pm 0.0037 \\
(150)\end{array}$ & $\begin{array}{l}14.8 \pm 2.5 \\
(157)\end{array}$ & $\begin{array}{c}0.64 \pm 0.15 \\
\quad(176)\end{array}$ & $\begin{array}{l}10.8 \pm 3.0 \\
\quad(157)\end{array}$ & $\begin{array}{l}0.99 \pm 0.14 \\
\quad(172)\end{array}$ & $\begin{array}{l}10.8 \pm 4.9 \\
\quad(146)\end{array}$ & $\begin{array}{l}2.77 \pm 0.73 \\
\quad(171)\end{array}$ & $\begin{array}{l}0.98 \pm 0.3 \\
\quad(165)\end{array}$ & $\begin{array}{l}0.30 \pm 0.04 \\
(169)\end{array}$ \\
\hline $\begin{array}{l}\text { Water and sediment } \\
\text { reference material }^{c}\end{array}$ & & & & & & & & & & & & & & & & \\
\hline Certified values & $1148 \pm 111$ & $2150 \pm 70$ & $1792 \pm 36$ & $540 \pm 40$ & $71 \pm 6$ & $9.3 \pm 0.5$ & $0.11 \pm 0.02$ & $0.0053 \pm 0.0009$ & $21.3 \pm 1.1$ & $0.39 \pm 0.06$ & $14.1 \pm 1.4$ & $0.51 \pm 0.05$ & $15.9 \pm 1.4$ & $2.92 \pm 0.26$ & $0.46 \pm 0.1$ & $0.18 \pm 0.03$ \\
\hline Measured values $^{d}$ & $\begin{array}{c}1148 \pm 31 \\
(48)\end{array}$ & $\begin{array}{l}2190 \pm 40 \\
(85)\end{array}$ & $\begin{array}{c}1810 \pm 18 \\
(48)\end{array}$ & $\begin{array}{l}560 \pm 20 \\
(85)\end{array}$ & $\begin{array}{c}67 \pm 2 \\
(48)\end{array}$ & $\begin{array}{l}9.1 \pm 0.2 \\
(85)\end{array}$ & $\begin{array}{c}0.10 \pm 0.02 \\
(14)\end{array}$ & $\begin{array}{c}0.0063 \pm 0.0004 \\
(85)\end{array}$ & $\begin{array}{l}21.4 \pm 0.6 \\
(48)\end{array}$ & $\begin{array}{l}0.36 \pm 0.02 \\
(85)\end{array}$ & $\begin{array}{l}15.2 \pm 0.7 \\
\quad(48)\end{array}$ & $\begin{array}{c}0.44 \pm 0.02 \\
(85)\end{array}$ & $\begin{array}{l}15.9 \pm 0.9 \\
(48)\end{array}$ & $\begin{array}{l}2.92 \pm 0.14 \\
(85)\end{array}$ & $\begin{array}{l}0.53 \pm 0.1 \\
(48)\end{array}$ & $\begin{array}{c}0.16 \pm 0.01 \\
(85)\end{array}$ \\
\hline
\end{tabular}




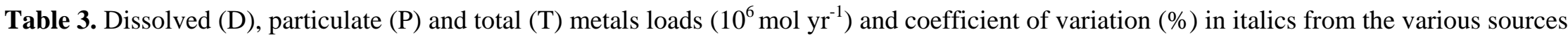
in the St Lawrence River.

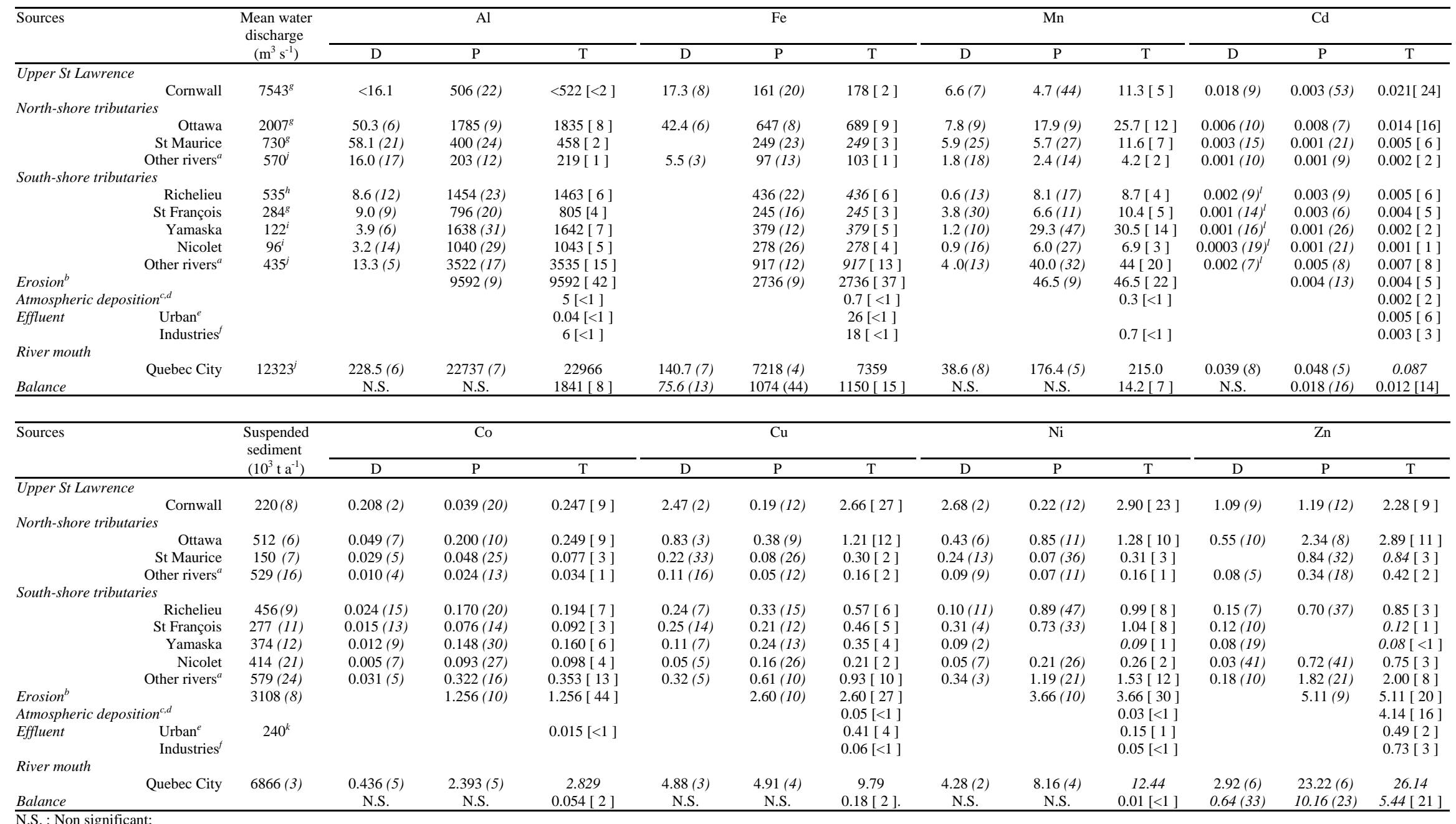

[ ] : percentage of total load;

$a$
${ }^{b}$

${ }^{c}$ and $^{d}$ : net direct atmospheric deposition was evaluated for a surface of the SLR of $1.74 \times 10^{9} \mathrm{~m}^{2}$

: data from Simonetti et al. (2000);
: Total deposition (wet and dry) was estimated in Bergeron and Poissant (2000) and Simonetti et al. (2000). Direct deposition values were estimated using a surface area of $1.74 \times 10^{9} \mathrm{~m}^{2}$ of the SLR; 


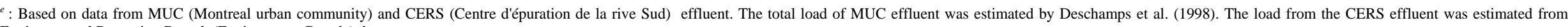
Environmental Protection Branch (Environment Canada) data;

: Based on data from Environment Canada. Total loads were estimated from direct discharges of 38 industrial plants in 1995;

data from Hydro-Quebec;

: data from Environment Canada;

: data from Quebec Ministry of the Environment;

: data from St Lawrence Centre;

$:$ data from Frenette et al. (1989); 


\section{FIGURE CAPTIONS}

Figure 1. Location of sampling stations along the St. Lawrence River and its main tributaries.

Figure 2. Relationship between calcium $(\mathrm{Ca})$ and conductivity at the main sampling stations, and relationship between calcium and the percentage of water from the upper St. Lawrence River at the river mouth (Quebec).

Figure 3. Variations of water discharge $(\square)$ and suspended particulate matter (SPM) discharge ( $(x)$ at the main sampling stations. (A) Ottawa River, (B) upper SLR, (C and E) mouth of the SLR, (D) relative contributions of the upper SLR, North and South Shore tributaries to the water discharge at the SLR mouth.

Figure 4. Temporal variations of minor element concentrations ( $\mathrm{Al}, \mathrm{Fe}$ and $\mathrm{Mn})$ at the two source end-member stations (Ottawa River and upper St. Lawrence River); ( $\square$ ) particulate and ( $(\mathbf{s})$ dissolved.

Figure 5. Temporal variations of trace element concentrations $(\mathrm{Cd}, \mathrm{Co}, \mathrm{Cu}, \mathrm{Ni}$ and $\mathrm{Z})$ at the two source end-member stations (Ottawa River and upper St. Lawrence River); ( $\square$ ) particulate and ( $\mathbf{z})$ dissolved.

Figure 6. Seasonal variations of minor and trace element concentrations (Al, Fe, Mn, Cd, Co, $\mathrm{Cu}, \mathrm{Ni}$ and $\mathrm{Zn}$ ) at the mouth of the St. Lawrence River between 1995 and 1999. There were 9-25 montly samples.

Figure 7. Seasonal variations of dissolved $\mathrm{Mn}$ and the percentage of water from tributaries at the river mouth between 1995 and 1999. There were 9-25 montly samples.

Figure 8. Relationships between $\mathrm{Ca}$ and minor elements (Fe and $\mathrm{Mn}$ ) at the river mouth between 1995 and 1999; ( $\square$ ) Ottawa River from June to October; (घ) Ottawa River from November to May ; ( $\boldsymbol{\Delta})$ Upper St. Lawrence River; $(\diamond)$ Mouth of the St. Lawrence River from June to October ; (*) Mouth of the St. Lawrence River from November to May. Station locations are on figure 1. 


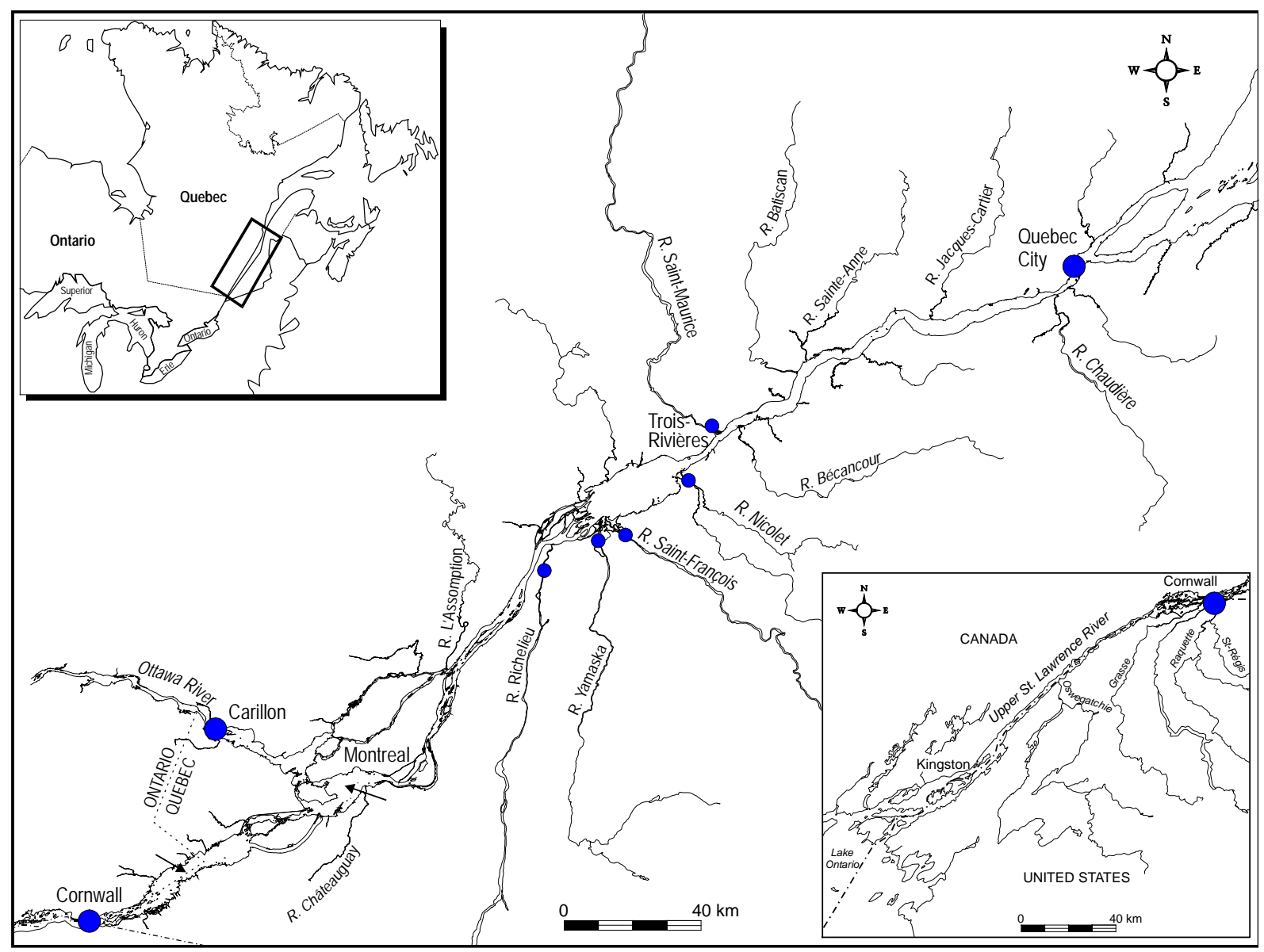

Fig 1 


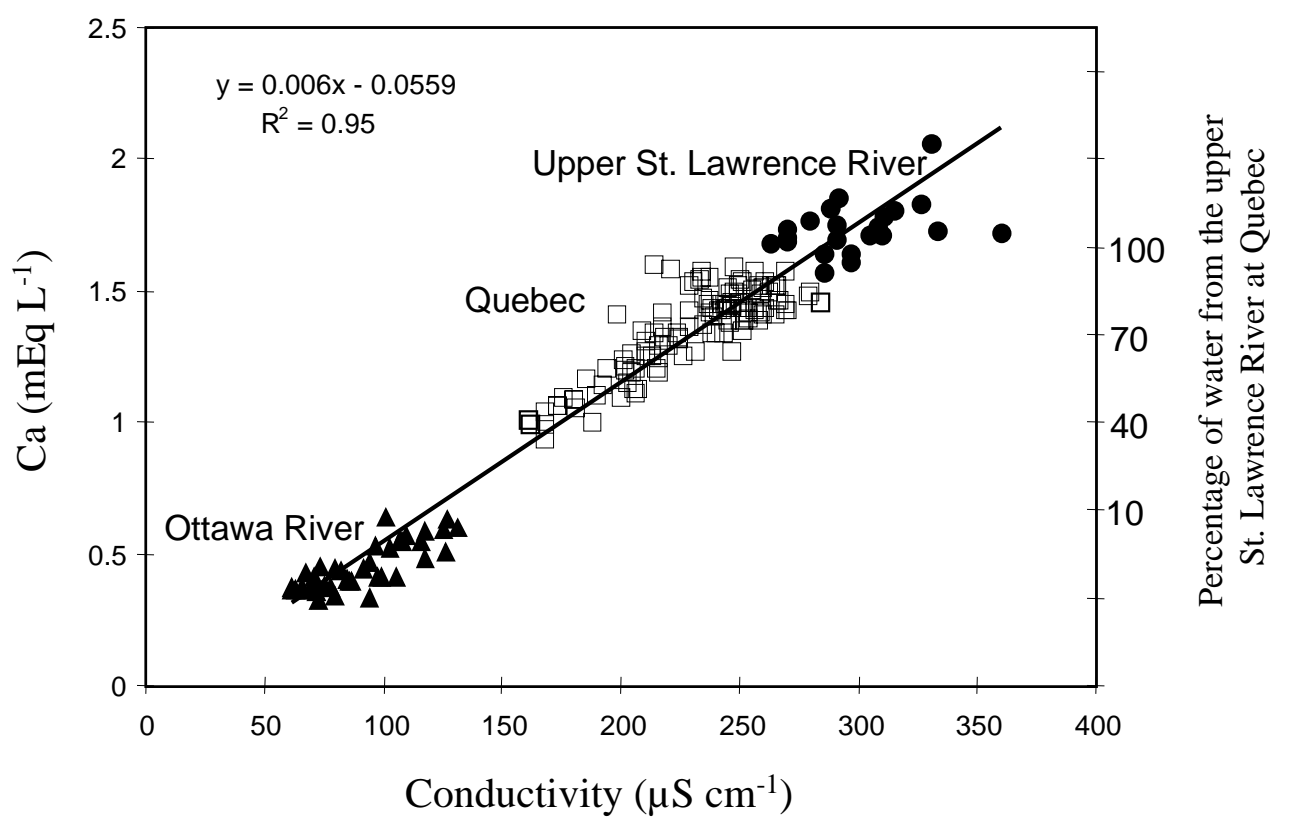

Fig 2 

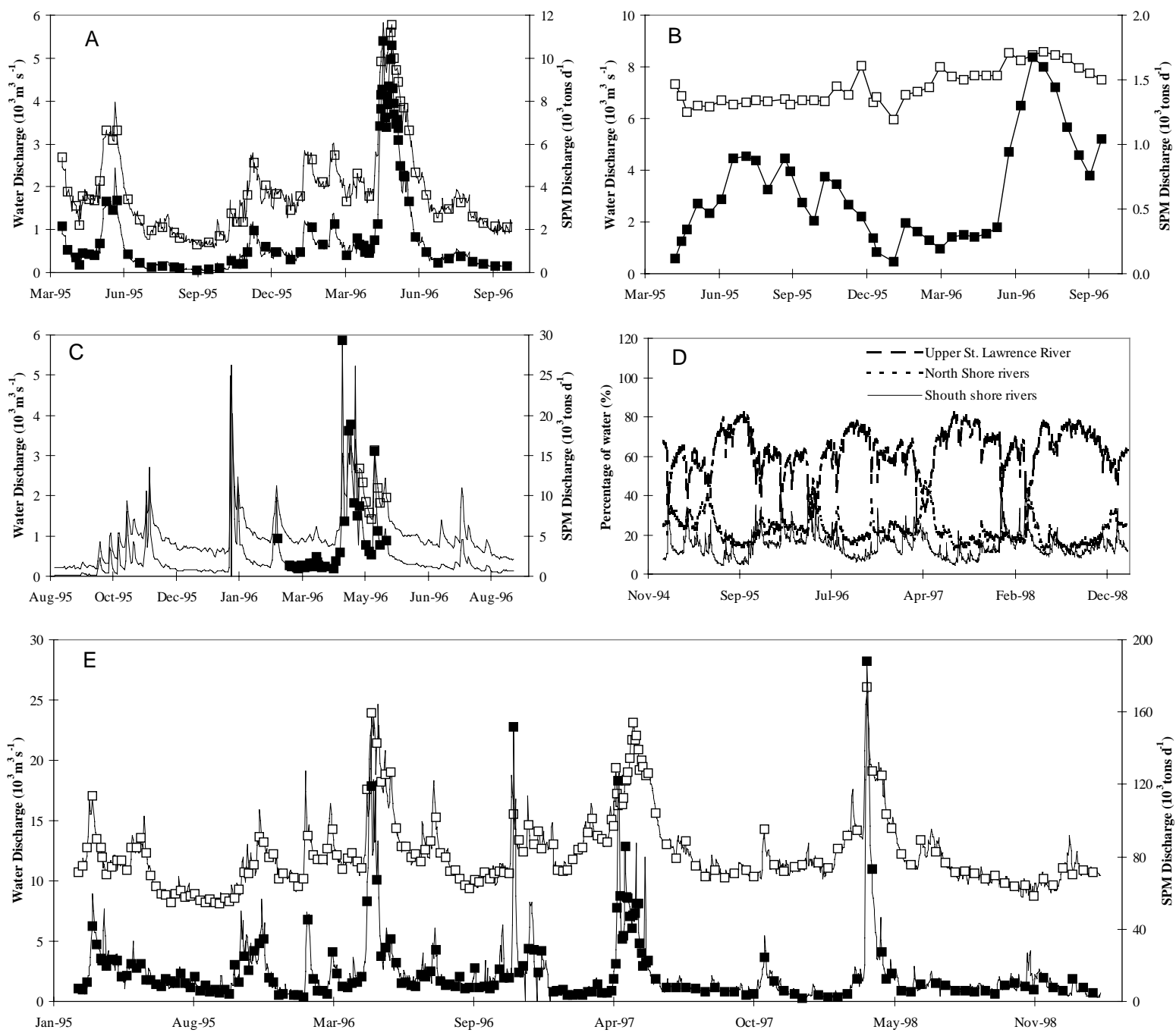

Fig 3 

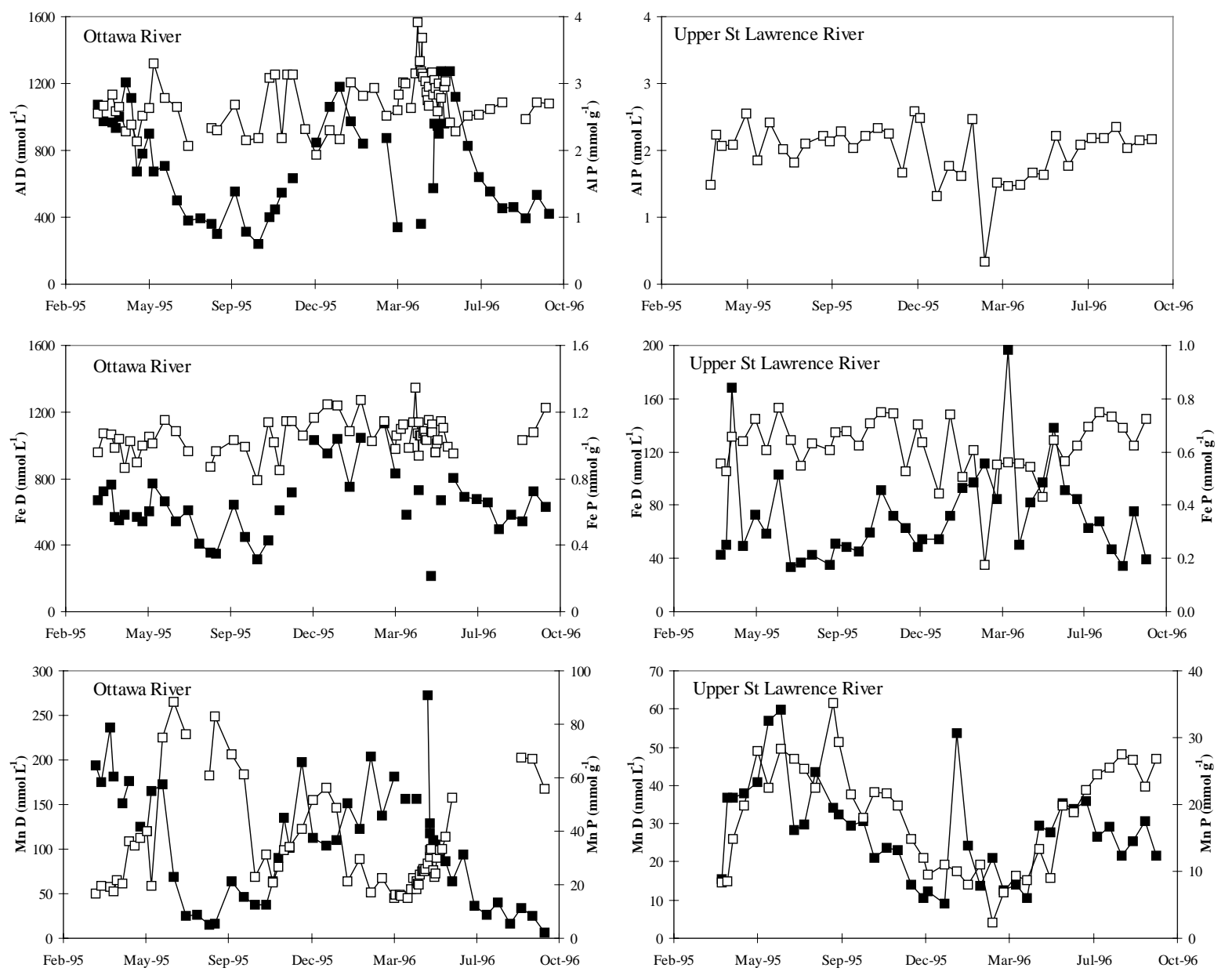

Fig 4 

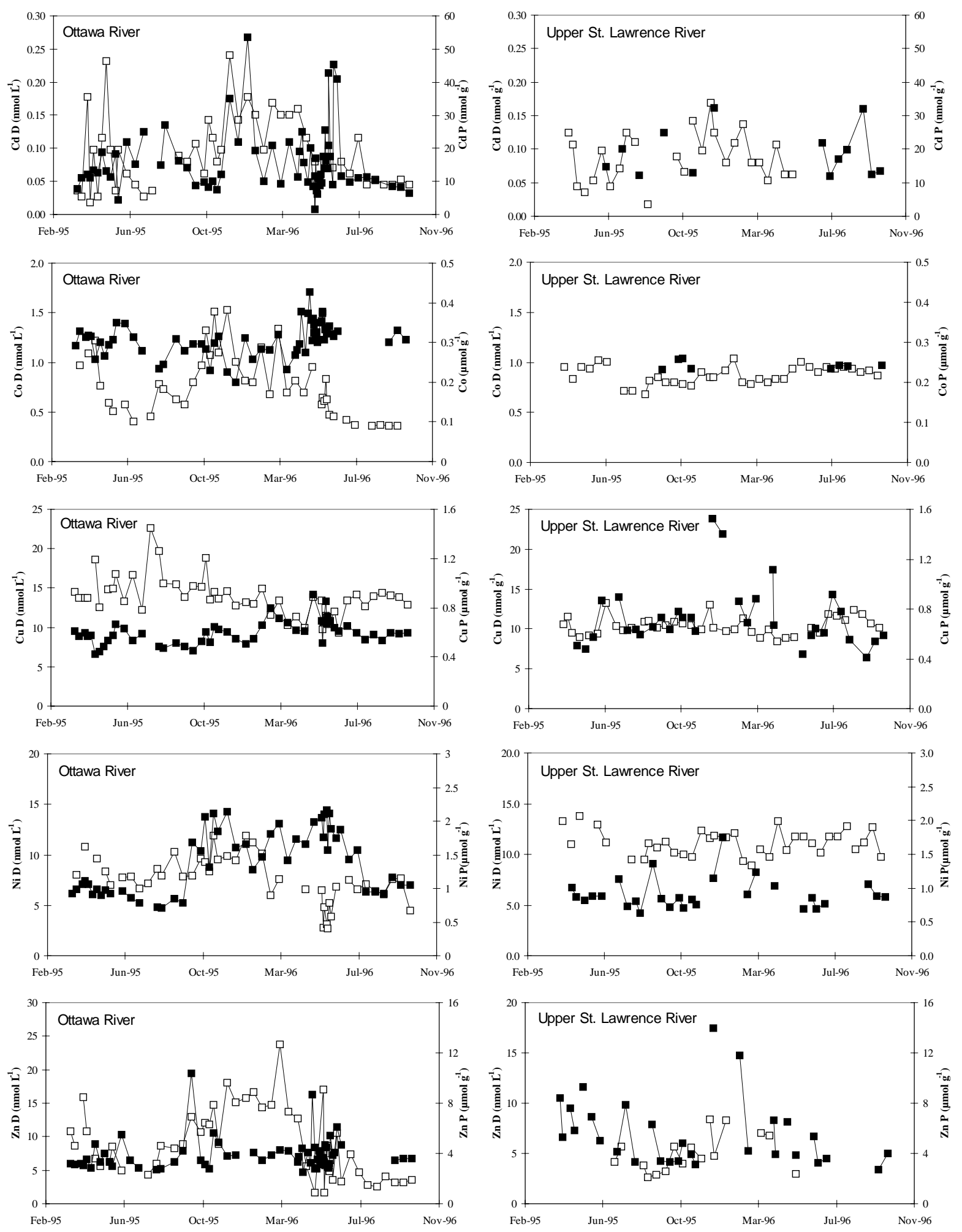

Fig 5 


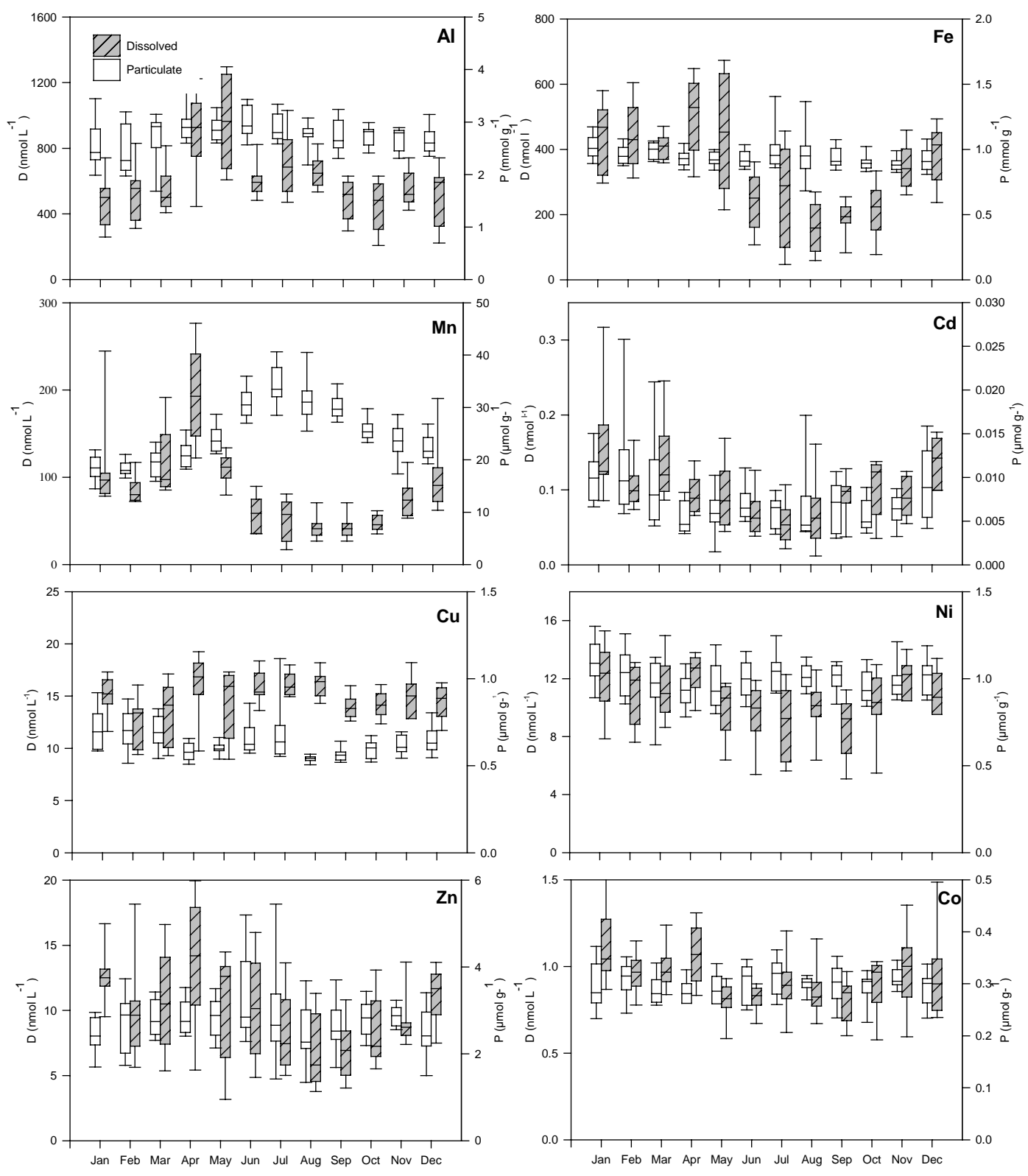

Fig 6 


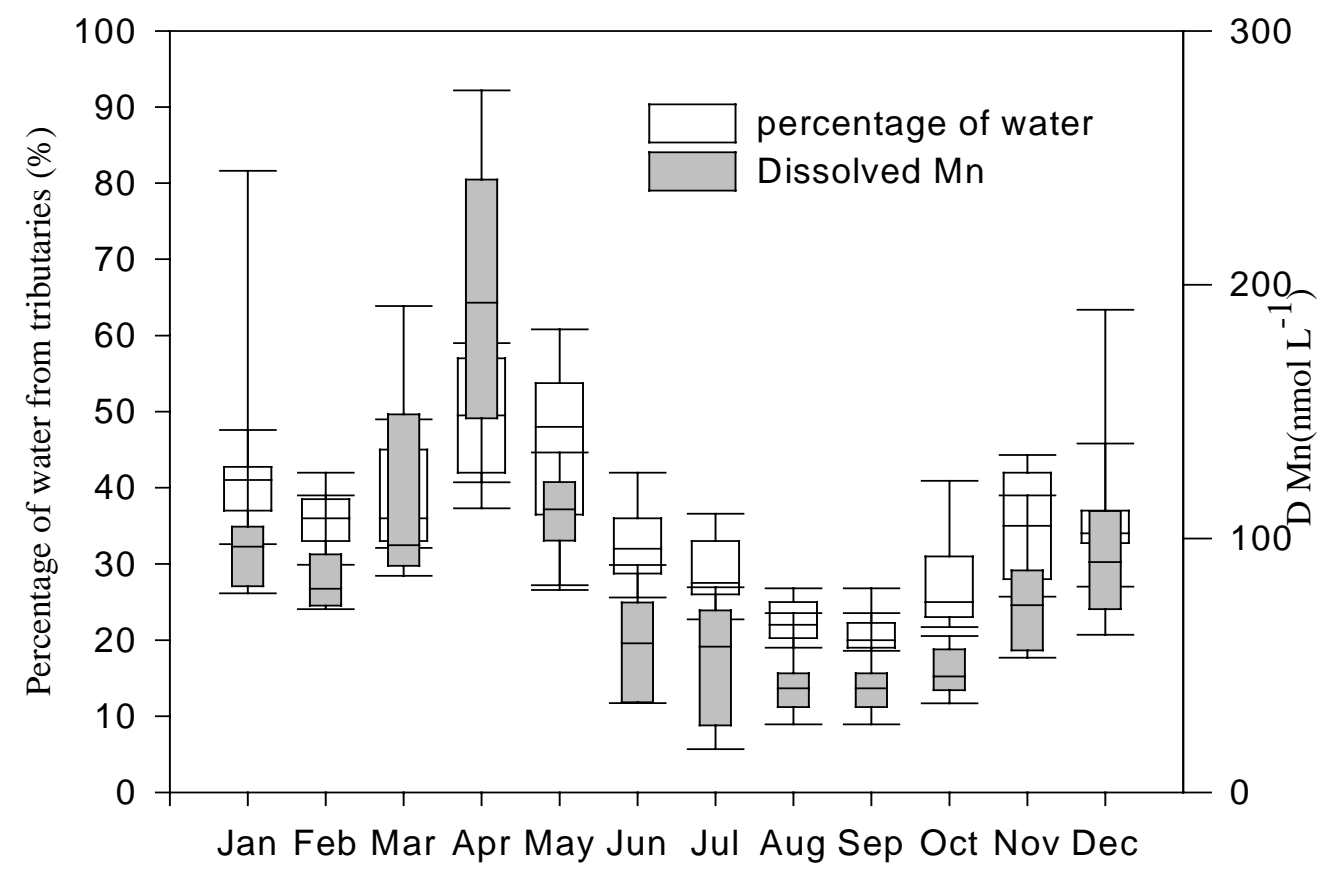

Fig 7 

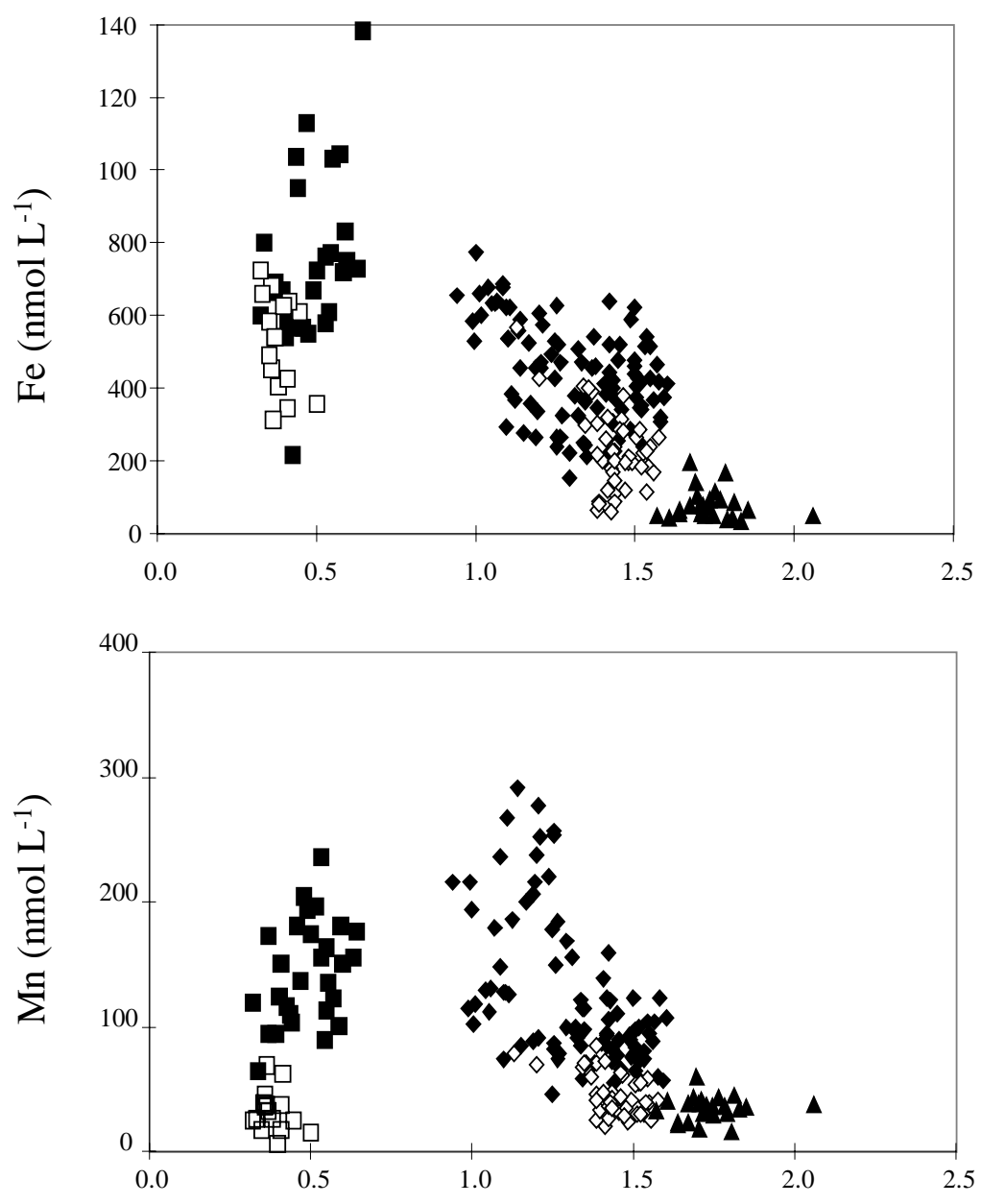

$\mathrm{Ca}\left(\mathrm{mEq} \mathrm{L} \mathrm{L}^{-1}\right)$

Fig 8 